\title{
The zinc-finger transcription factor MAZR regulates iNKT cell subset differentiation
}

\author{
Maria Jonah Orola ${ }^{1,5} \cdot$ Caroline Tizian $^{1,6} \cdot$ Ci Zhu $^{2} \cdot$ Liisa Andersen $^{1} \cdot$ Alexandra Franziska Gülich ${ }^{1} \cdot$ Marlis Alteneder $^{1}$. \\ Tatjana Stojakovic ${ }^{3}$. Ursula Wiedermann ${ }^{4} \cdot$ Michael Trauner $^{2} \cdot$ Wilfried Ellmeier $^{1} \cdot$ Shinya Sakaguchi ${ }^{1}$ (D)
}

Received: 18 July 2018 / Revised: 19 April 2019 / Accepted: 29 April 2019 / Published online: 7 May 2019

(c) The Author(s) 2019

\begin{abstract}
Invariant natural killer T (iNKT) cells represent a subgroup of innate-like $\mathrm{T}$ cells and play an important role in immune responses against certain pathogens. In addition, they have been linked to autoimmunity and antitumor immunity. iNKT cells consist of several subsets with distinct functions; however, the transcriptional networks controlling iNKT subset differentiation are still not fully characterized. Myc-associated zinc-finger-related factor (MAZR, also known as PATZ1) is an essential transcription factor for $\mathrm{CD}^{+}$lineage differentiation of conventional $\mathrm{T}$ cells. Here, we show that MAZR plays an important role in iNKT cells. T-cell lineage-specific deletion of MAZR resulted in an iNKT cell-intrinsic defect that led to an increase in iNKT2 cell numbers, concurrent with a reduction in iNKT1 and iNKT17 cells. Consistent with the alteration in the subset distribution, deletion of MAZR also resulted in an increase in the percentage of IL-4-producing cells. Moreover, MAZR-deficient iNKT cells displayed an enhanced expression of Erg2 and ThPOK, key factors for iNKT cell generation and subset differentiation, indicating that MAZR controls iNKT cell development through fine-tuning of their expression levels. Taken together, our study identified MAZR as an essential transcription factor regulating iNKT cell subset differentiation and effector function.
\end{abstract}

Keywords iNKT cell subset differentiation $\cdot$ iNKT cell function $\cdot$ Transcriptional regulation $\cdot$ PATZ1/MAZR

$\begin{array}{ll}\text { Abbreviations } \\ \text { ALT } & \text { Alanine aminotransferase } \\ \text { AST } & \text { Aspartate aminotransferase } \\ \text { BM } & \text { Bone marrow } \\ \text { CD1d-tet } & \text { Murine CD1d tetramer loaded with PBS-57 }\end{array}$

Maria Jonah Orola and Caroline Tizian contributed equally to this work.

Electronic supplementary material The online version of this article (https://doi.org/10.1007/s00018-019-03119-z) contains supplementary material, which is available to authorized users.

Shinya Sakaguchi

shinya.sakaguchi@meduniwien.ac.at

1 Division of Immunobiology, Institute of Immunology, Center for Pathophysiology, Infectiology and Immunology, Medical University of Vienna, 1090 Vienna, Austria

2 Hans Popper Laboratory of Molecular Hepatology, Division of Gastroenterology and Hepatology, Department of Internal Medicine III, Medical University of Vienna, 1090 Vienna, Austria

3 Clinical Institute of Medical and Chemical Laboratory Diagnostics, University Hospital Graz, 8036 Graz, Austria

$\begin{array}{ll}\text { DN } & \text { Double-negative } \\ \text { DP } & \text { Double-positive } \\ \text { GATA3 } & \text { GATA-binding protein 3 } \\ \text { iNKT cells } & \text { Invariant natural killer T cells } \\ \text { MAZR } & \text { Myc-associated zinc-finger-related factor } \\ \text { PLZF } & \text { Promyelocytic leukemia zinc finger } \\ \text { ROR } \gamma \mathrm{t} & \text { RAR-related orphan receptor gamma } \\ \text { Runx } & \text { Runt-related transcription factor } \\ \text { T-bet } & \text { T-box 21 } \\ \text { TCR } & \text { T-cell receptor }\end{array}$

4 Institute of Specific Prophylaxis and Tropical Medicine, Center for Pathophysiology, Infectiology and Immunology, Medical University of Vienna, 1090 Vienna, Austria

5 Present Address: Institute of Specific Prophylaxis and Tropical Medicine, Center for Pathophysiology, Infectiology and Immunology, Medical University of Vienna, 1090 Vienna, Austria

6 Present Address: Institute of Microbiology and Infectious Diseases and Immunology, Charité-University Medical Centre Berlin (CBF), 12203 Berlin, Germany 
ThPOK T-helper-inducing POZ/Krueppel-like factor $\alpha$-GalCer

\section{Introduction}

Invariant natural killer T (iNKT) cells are a small subgroup of T cells expressing semi-invariant T-cell receptors (TCRs), which consist of an invariant $\alpha$ chain and a limited repertoire of $\beta$ chains $[1,2]$. They recognize lipid antigens such as alpha-galactosylceramide ( $\alpha$-GalCer) presented by CD1d, a non-classical MHC class I molecule, and are capable of rapidly producing a large amount of cytokines upon activation [3, 4]. iNKT cells diverge from conventional T cells at the double-positive (DP) stage of thymocyte development, where iNKT TCR-expressing thymocytes are positively selected by glycolipid-CD1d complexes through DP-DP thymocyte interaction $[1,5,6]$. Upon positive selection, iNKT cell precursors start to express the transcription factor early growth response protein 2 (Egr2) at a high level [7]. This leads to the induction of promyelocytic leukemia zinc finger (PLZF) and c-myc expression, which is accompanied by the acquisition of effector properties and a robust proliferation [8-11]. The classical view ("linear differentiation" model) on iNKT cell differentiation defines, based on the expression of CD24, CD44, CD69 and NK1.1, several sequential iNKT cell maturation stages, starting from the most immature NKT cells designated as stage $0\left(\mathrm{CD} 24^{+} \mathrm{CD} 44^{-} \mathrm{CD} 69^{+}\right)$, followed by stage $1\left(\mathrm{CD} 24^{-} \mathrm{CD} 44^{-} \mathrm{NK} 1.1^{-}\right)$, stage $2\left(\mathrm{CD} 24^{-} \mathrm{CD} 44^{+} \mathrm{NK} 1.1^{-}\right)$ and stage $3\left(\mathrm{CD} 24^{-} \mathrm{CD} 44^{+} \mathrm{NK} 1.1^{+}\right)$subsets [6, 12-14]. However, recent studies revealed that each of the classical developmental stages contains terminally differentiated iNKT cells $[15,16]$. Based on the expression pattern of the transcription factors PLZF, T-box 21 (T-bet) and RARrelated orphan receptor gamma $(\mathrm{ROR} \gamma \mathrm{t})$, three distinct iNKT cell subsets have been defined ("lineage diversification" model), analogous to helper $\mathrm{T}$ and innate lymphoid cells: iNKT1 $\left(\right.$ T-bet $\left.^{\text {hi }}{ }^{\text {PLZF }}{ }^{\text {lo }}\right)$, iNKT2 $\left(\right.$ PLZF $^{\text {hi }}$ ROR $\left.\gamma \mathrm{t}^{-}\right)$and iNKT17 $\left(\mathrm{PLZF}^{\mathrm{mid}} \mathrm{ROR} \gamma \mathrm{t}^{+}\right)[6,17,18]$. iNKT1 cells, which are almost identical to stage 3 iNKT cells, produce both IFN- $\gamma$ and IL- 4 upon activation, whereas the iNKT17 cell subset is included in stage 2 iNKT cells and mainly produces IL-17. iNKT 2 cells display a stage 1/stage 2 phenotype and express IL-4. Owing to their unique features, iNKT cells are implicated in controlling a diversity of different types of immune reactions, including antimicrobial responses as well as antitumor immunity $[3,19,20]$. Although key transcription factors controlling iNKT cell development have been identified $[5,14,17]$, the fine-tuning of iNKT subset differentiation is not fully understood.

Myc-associated zinc-finger-related factor (MAZR; also known as PATZ1) is a member of the BTB/POZ domain

containing zinc-finger transcription factor protein family, which also includes PLZF and T-helper-inducing POZ/ Krueppel-like factor (ThPOK; also known as ZBTB7b) proteins $[21,22]$. We previously demonstrated that MAZR is a negative regulator of $C d 8$ expression in double-negative (DN) thymocytes and that it is part of the transcription factor network controlling helper versus cytotoxic lineage decision of DP thymocytes [23, 24]. MAZR represses ThPOK expression in MHC class I-signaled thymocytes, presumably via binding to the Thpok silencer, and thereby prevents the redirection of MHC class I-signaled thymocytes into the helper lineage [24]. More recently, we have also shown that MAZR and Runt-related transcription factor (Runx) proteins synergistically repress ThPOK expression during cytotoxic lineage development and that MAZR is required for the maintenance of ThPOK repression in $\mathrm{CD} 8^{+} \mathrm{T}$ cells [25]. Although these studies revealed an essential role for MAZR at multiple stages of conventional T-cell development, its role in the development of innate-like $\mathrm{T}$ cells including iNKT cells remains unknown. MAZR is expressed in the iNKT cell lineage, as reported in the Immunological Genome Project database [26], and a recent transcriptome comparison of each iNKT subset revealed an upregulation of MAZR expression in iNKT2 cells compared to other iNKT cell subsets [27]. Moreover, both ThPOK (which is a MAZR target gene) and Runx proteins (which are MAZR interacting factors) are key regulators of iNKT cell development [28-33]. Together, these data suggest a role for MAZR in iNKT cells. In this study, by analyzing mice with a T-cell-specific deletion of MAZR, we observed an enlargement of the CD44 ${ }^{+} \mathrm{NK} 1.1^{-}$stage 2 iNKT cell population, which was accompanied with elevated expression of CD4 and ThPOK in iNKT cells. The analysis of T-bet, PLZF and ROR $\gamma t$ expression revealed that the deletion of MAZR led to an increase in the number of iNKT2 cells, while iNKT1 and iNKT17 cell numbers were reduced in the absence of MAZR. The alteration in iNKT cell subset differentiation, which was caused by iNKT cell-intrinsic defects, resulted in enhanced production of IL-4, along with a reduction in IL-17A secretion, both upon in vitro PMA/ionomycin and in vivo $\alpha$-GalCer stimulation. Finally, the deletion of MAZR led to an increase in Egr2 expression, a key factor required for the acquisition of an iNKT cell effector program and for iNKT cell subset differentiation [7, 34], at stages 2 and 3 of iNKT cell development. This suggests that MAZR controls iNKT cell development through regulating Egr2 expression, in addition to its repression of ThPOK expression. Together, our data identified MAZR as an essential regulator of iNKT cell subset differentiation. 


\section{Materials and methods}

\section{Mice}

$\mathrm{Mazr}^{\mathrm{f} / \mathrm{f}}$ [35], Runx3 $3^{\mathrm{f} / \mathrm{f}}$ [36] and Thpok-GFP knock-in [37] mice have been described previously. Lck-Cre and Cd4Cre mice [38] were kindly provided by Dr. Chris Wilson. Six-to-ten-week-old mice were used for experiments. All the mice used for experiments were backcrossed onto a C57BL/6 background and were maintained in the preclinical research facility of the Medical University of Vienna. Animal husbandry and experimentation was performed under the national laws (Federal Ministry of Education, Science and Research, Vienna, Austria) and ethics committees of the Medical University of Vienna and according to the guidelines of FELASA, which match that of ARRIVE.

\section{Cell preparation}

Single-cell suspensions of thymocytes and splenocytes were prepared as previously described [23]. For the isolation of hepatic mononuclear cells, livers were perfused with $1 \times$ PBS, were cut into small pieces with scissors and scalpels, and were digested with $600 \mathrm{U} / \mathrm{ml}$ collagenase D (Roche) and $10 \mathrm{U} / \mathrm{ml}$ DNase I (Roche) in RPMI1640 medium (Sigma) containing $2 \% \mathrm{FCS}$ (Sigma) for $30 \mathrm{~min}$ at $37{ }^{\circ} \mathrm{C}$ in a shaker. Subsequently, hepatic cells were filtered through a $70 \mu \mathrm{m}$ strainer and resuspended in a 35\% Percoll (GE Healthcare) solution. After centrifugation at $700 \mathrm{~g}$ at room temperature for $15 \mathrm{~min}$, cells at the high-density fraction were collected and red blood cells were lysed in $1 \times$ BD Pharm buffer (BD Biosciences). Subsequently, cells were stained with appropriate antibodies.

\section{Enrichment of iNKT cells}

For some experiments, thymic and splenic iNKT cells were enriched by negative depletion. Single-cell suspensions of thymocytes and splenocytes were incubated with biotinylated anti-CD8 $\alpha$ (53-6.7) and anti-CD19 (6D5) antibodies (Biolegend), followed by the incubation with BD iMag Streptavidin Particles Plus (BD Biosciences). Negative depletion was performed according to the manufacturer's instruction.

\section{Antibodies and flow cytometry}

Antibodies used in this study are listed in Table S1. Brilliant violet 421-, or PE-conjugated murine CD1d tetramers loaded with PBS-57 (CD1d-tet) were kindly provided by the National Institutes of Health (NIH) Tetramer Facility.
Thymocytes, splenocytes, and hepatic monocellular cells were first incubated with eF506 Viability Dye (Thermo Fisher Scientific) as well as purified anti-CD16/CD32 antibody (BD Biosciences) to avoid unspecific antibody binding. Subsequently, appropriate antibodies including CD1dtet were added and cells were incubated on ice for $30 \mathrm{~min}$. For the intracellular staining of transcription factors, Foxp3/ Transcription Factor Staining Buffer Kit (Thermo Fisher Scientific) was used according to manufacture's instruction. Intracellular MAZR expression was detected by anti-MAZR/ PATZ1 antibody (D-5: Santa Cruz Biotechnology), followed by the staining of Alexa Fluor 647 anti-mouse IgG $_{1}$ antibody (RMG1-1: Biolegend). Annexin V staining was performed using Annexin V Apoptosis Detection Kit (Thermo Fisher Scientific). Flow cytometric data were collected with LSRII or Fortessa (BD Biosciences) and were analyzed with Flowjo software (Treestar).

\section{In vivo BrdU incorporation}

Mice were given a single i.p. injection of $1 \mathrm{mg} B r d U$ (Sigma) diluted in $200 \mu \mathrm{l}$ of $1 \times$ PBS, followed by 2 days BrdU administration in drinking water $(1 \mathrm{mg} / \mathrm{ml})$. Mice were then euthanized and single-cell suspensions of thymocytes and splenocytes were prepared. BrdU incorporation was measured using BrdU Flow Kit (BD Biosciences) according to manufacturer's instruction.

\section{Measurement of intracellular cytokine production}

Five million thymocytes or splenocytes were resuspended in $3 \mathrm{ml}$ of complete RPMI1640 medium [Sigma, supplemented with 10\% FCS (Sigma), $100 \mathrm{U} / \mathrm{ml}$ penicillin-streptomycin (GE Healthcare), 2 mM L-glutamine (Sigma), $0.1 \mathrm{mM}$ nonessential amino acid (Lonza), $1 \mathrm{mM}$ sodium pyruvate (GE Healthcare), $55 \mu \mathrm{M} \beta$-mercaptoethanol (Sigma)] containing $50 \mathrm{ng} / \mathrm{ml}$ of phorbol 12-myristate 13-acetate (PMA; Sigma) and $500 \mathrm{ng} / \mathrm{ml}$ of ionomycin (Sigma) in the presence of Golgistop (BD Biosciences). Cells were harvested after $4.5 \mathrm{~h}$ incubation at $37^{\circ} \mathrm{C}$, and were stained with CD1d-tet as well as appropriate antibodies for surface markers. Cells were fixed with BD fixation buffer (BD Biosciences), and were stained for intracellular cytokines in $1 \times \mathrm{BD}$ perm buffer (BD Biosciences). Cytokine production was measured by LSRII or Fortessa (BD Biosciences).

\section{Generation of bone-marrow chimeric mice}

Bone-marrow cells were incubated with biotinylated antiCD3e (145-2C11; BD Biosciences) and anti-CD90.2 (532.1; BD Biosciences), followed by negative depletion with streptavidin beads (BD Biosciences). T-cell-depleted bonemarrow cells from $\mathrm{Mazr}^{+/+}$Thpok $^{+/ \mathrm{GFP}}$ Lck-Cre or $\mathrm{Mazr}^{\mathrm{f} /}$ 
a

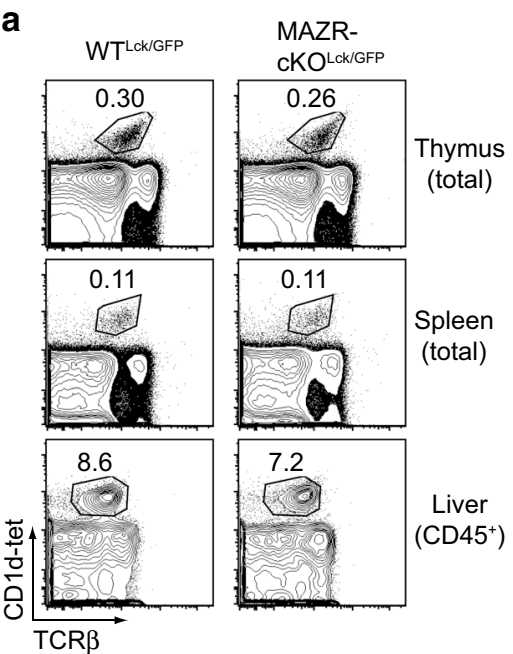

C Thymus

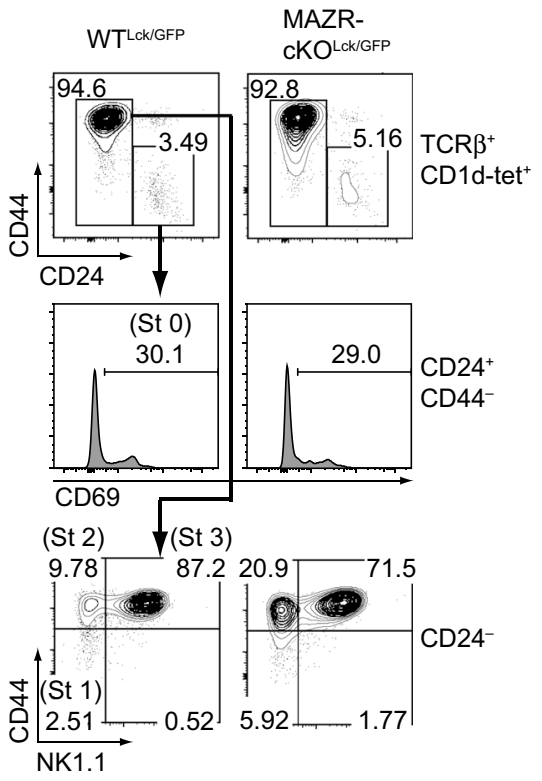

e Spleen WT Lck/GFP MAZR(St 2) (St 3)

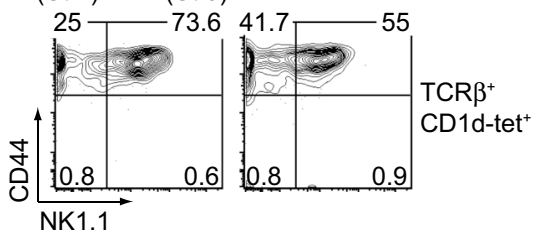

\section{b}

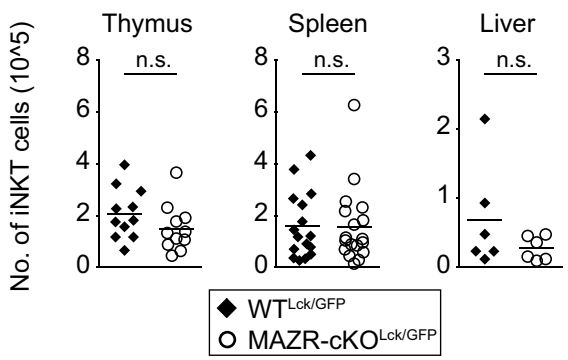

d

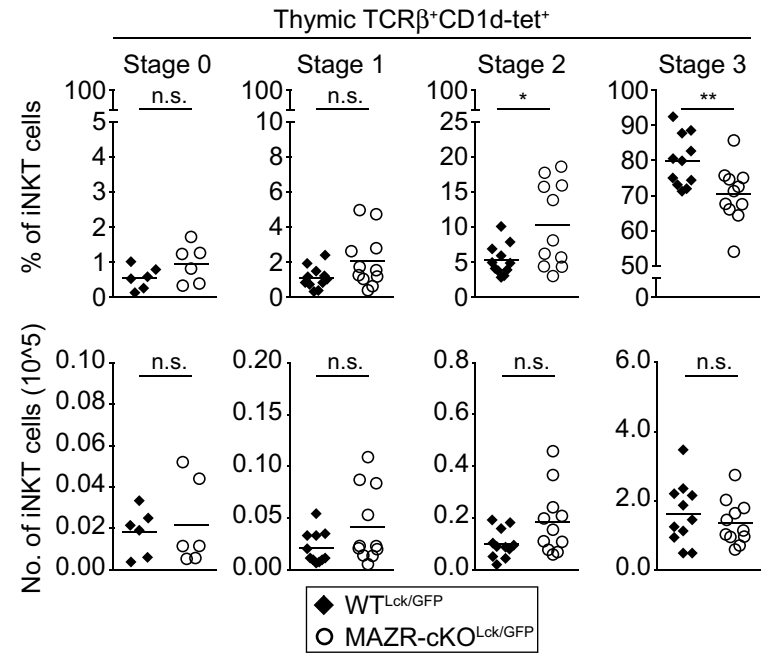

f

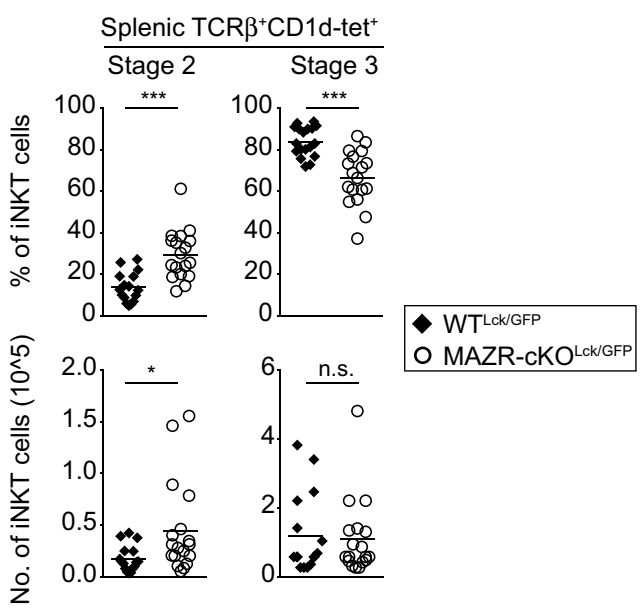


4Fig. 1 Deletion of MAZR in T cells leads to an increase in the number of stage 2 iNKT cells. a Flow cytometry analysis showing murine CD1d tetramers loaded with PBS-57 (CD1d-tet) staining and TCR $\beta$ expression on thymocytes, splenocytes, and CD $45^{+}$ gated hepatic lymphocytes isolated from $\mathrm{WT}^{\mathrm{Lck} / \mathrm{GFP}}$ and MAZR$\mathrm{cKO}^{\mathrm{Lck} / \mathrm{GFP}}$ mice. Numbers indicate the percentages of iNKT cells. b Diagrams showing the total cell numbers of iNKT cells in thymi, spleens, and livers of $\mathrm{WT}^{\mathrm{Lck} / \mathrm{GFP}}$ and MAZR-cKO $\mathrm{Lck}^{\mathrm{Lck} / \mathrm{GFP}}$ mice. c Flow cytometry analysis showing CD44 and CD24 expression on TCR $\beta^{+}$CD1d-tet ${ }^{+}$thymocytes (upper panel), CD69 expression on $\mathrm{TCR} \beta^{+} \mathrm{CD} 1 \mathrm{~d}-$ tet $^{+} \mathrm{CD} 44^{-} \mathrm{CD} 24^{+}$thymocytes (middle panel) and CD44 and NK1.1 expression on $\mathrm{TCR} \beta^{+} \mathrm{CD} 1 \mathrm{~d}-$ tet $^{+} \mathrm{CD} 24^{-}$thymocytes (lower panel) isolated from $\mathrm{WT}^{\mathrm{Lck} / \mathrm{GFP}}$ and MAZR-cKO $\mathrm{Mck}^{\mathrm{Lck}}$ GFP mice. Gating regions for $\mathrm{TCR} \beta^{+} \mathrm{CD} 1 \mathrm{~d}-$ tet $^{+} \mathrm{CD} 44^{-} \mathrm{CD} 24^{+}$and $\mathrm{TCR} \beta^{+} \mathrm{CD} 1 \mathrm{~d}-\mathrm{tet}^{+} \mathrm{CD} 24^{-}$thymocytes are indicated in upper panel, while regions for stage $0\left(\mathrm{St} 0 ; \mathrm{CD} 24^{+} \mathrm{CD} 44^{-} \mathrm{CD} 69^{+}\right)$, stage 1 (St 1 ; $\mathrm{CD} 24^{-} \mathrm{CD} 44^{-} \mathrm{NK} 1.1^{-}$), stage 2 (St 2; CD24-CD44+ ${ }^{+} \mathrm{NK} 1.1^{-}$), and stage 3 (St 3; CD2 $4^{-} \mathrm{CD} 44^{+} \mathrm{NK} 1.1^{+}$) iNKT cells are shown in middle and lower panels. Numbers indicate the percentages of cells within the respective regions. d Diagrams showing the percentages (upper panel) and total cell numbers (lower panel) of thymic stage 0 (far left panel), stage 1 (left panel), stage 2 (right panel), and stage 3 (far right panel) iNKT cells in $\mathrm{WT}^{\mathrm{Lck} / \mathrm{GFP}}$ and MAZR-cKO ${ }^{\mathrm{Lck} / \mathrm{GFP}}$ mice. e Flow cytometry analysis showing CD44 and NK1.1 expression on $\mathrm{TCR} \beta^{+} \mathrm{CD} 1 \mathrm{~d}-$ tet $^{+}$splenocytes isolated from $\mathrm{WT}^{\mathrm{Lck} / \mathrm{GFP}}$ and MAZR$\mathrm{cKO}^{\mathrm{Lck} / \mathrm{GFP}}$ mice. Gating regions for stage $2\left(\mathrm{St} 2 \mathrm{CD}^{+} 4^{+} \mathrm{NK} 1.1^{-}\right)$ and stage 3 (St $3 ; \mathrm{CD}_{4} 4^{+} \mathrm{NK} 1.1^{+}$) iNKT cells are shown in the plots. Numbers indicate the percentages of cells within the respective regions. f Diagrams showing the percentages (upper panel) and total cell numbers (lower panel) of splenic stage 2 (left panel) and stage 3 (right panel) iNKT cells in WT $\mathrm{WT}^{\mathrm{Lck} / \mathrm{GFP}}$ and MAZR-cKO ${ }^{\mathrm{Lck} / \mathrm{GFP}}$ mice. a, c, e Data are representative of at least ten mice analyzed in at least five independent experiments, except for thymic stage 0 iNKT cell analysis (c), where data are representative of six mice analyzed in five independent experiments. b,d, f Each dot represents one mouse. Horizontal bars indicate mean values

${ }^{\mathrm{f}} \mathrm{Thpok}^{+/ \mathrm{GFP}}$ Lck-Cre mice (both CD45.2 ${ }^{+}$) were mixed at a 1:1 ratio with $\mathrm{CD} 45.1^{+}$bone-marrow cells, and a total of $4 \times 10^{6}$ cells were injected into the tail vein of lethally irradiated (8.25 Gy) CD $45.1^{+}$congenic mice. Eight weeks after transplantation, reconstituted mice were sacrificed, and iNKT cell development was analyzed.

\section{a-GaICer treatment}

$\alpha$-GalCer (KRN-7000, Funakoshi) was dissolved in vehicle $(5.6 \%$ sucrose, $0.75 \%$ L-histidine, and $0.5 \%$ Tween-20) to make $200 \mu \mathrm{g} / \mathrm{ml}$ stock solution. The stock solution was diluted 1:20 with PBS (Sigma), and mice were administrated a single intravenous injection of $\alpha$-GalCer at $100 \mathrm{ng} / \mathrm{g}$ of body weight. Control mice were administrated an equivalent volume of vehicle diluted in PBS. Ninety minutes after administration mice were euthanized, and single-cell suspensions of splenocytes and hepatic lymphocytes were prepared, incubated in complete RPMI-1640 medium containing GolgiPlug (1:1000) and GolgiStop (1:1500) (BD Biosciences) for $2 \mathrm{~h}$ at $37{ }^{\circ} \mathrm{C}$, and analyzed for cytokine production in iNKT cells. Twenty-four hours after $\alpha$-GalCer administration sera were prepared, and the levels of alanine aminotransferase (ALT) and aspartate aminotransferase (AST) were measured enzymatically (Roche Diagnostics, Mannheim, Germany).

\section{Statistical analysis}

An unpaired Student's $t$ test was performed for statistical analysis using Prism 6 software (GraphPad), unless otherwise indicated. The $p$ values were defined as follows: ${ }^{*} p<0.05 ;{ }^{* *} p<0.01 ; * * *<0.001 ;$ n.s., not significant.

\section{Results}

\section{Loss of MAZR leads to an increase in CD44 ${ }^{+} \mathrm{NK} 1.1^{-}$ stage 2 iNKT cells}

To test the role of MAZR during iNKT cell development, we analyzed mice with a T-cell-specific deletion of MAZR using the $L c k$-Cre deleter strain $\left(M_{a z r}{ }^{\mathrm{f} / \mathrm{f}} L c k\right.$-Cre) $[35,38]$. In addition, since MAZR represses ThPOK expression in cytotoxic T cells $[24,25]$, and since ThPOK expression is dynamically modulated during iNKT cell development [28, 29], we introduced a Thpok-GFP knock-in reporter allele $\left(\right.$ Thpok $\left.^{+/ \mathrm{GFP}}\right)$ into MAZR-deficient mice, allowing us to monitor Thpok expression by GFP expression [37]. In the end, Mazr ${ }^{\mathrm{f} / \mathrm{f}} \mathrm{Thpok}^{+/ \mathrm{GFP}}$ Lck-Cre and control $\mathrm{Mazr}^{+/+} \mathrm{Thpok}^{+/ \mathrm{GFP}}$ Lck-Cre mice (for simplicity designated MAZR-cKO ${ }^{\text {Lck/GFP }}$ and $\mathrm{WT}^{\mathrm{Lck} / \mathrm{GFP}}$ throughout the manuscript, respectively) were used to investigate the impact of MAZR deficiency on iNKT cell development. The total numbers of iNKT cells in thymus, spleen and liver were similar between $\mathrm{WT}^{\mathrm{Lck} / \mathrm{GFP}}$ and MAZR-cKO ${ }^{\mathrm{Lck} / \mathrm{GFP}}$ mice (Fig. 1a, b). However, the percentages of thymic stage 2 $\left(\mathrm{CD} 24^{-} \mathrm{CD} 44^{+} \mathrm{NK} 1.1^{-}\right)$iNKT cells were significantly increased in MAZR-cKO ${ }^{\mathrm{Lck} / \mathrm{GFP}}$ mice compared to $\mathrm{WT}^{\mathrm{Lck} / \mathrm{GFP}}$ mice, along with a corresponding reduction in the percentage of stage $3\left(\mathrm{CD} 24^{-} \mathrm{CD} 44^{+} \mathrm{NK} 1.1^{+}\right)$iNKT cells (Fig. 1c, d). A similar increase in the percentage of stage 2 iNKT cells was also observed in spleen and liver of MAZR-cKO ${ }^{\mathrm{Lck} / \mathrm{GFP}}$ mice (Fig. 1e, f; Fig. S1a, S1b). Moreover, the total number of splenic stage 2 iNKT cells was elevated in the absence of MAZR. These results suggest that MAZR negatively regulates the differentiation of stage 2 iNKT cells.

Previous studies have demonstrated that the majority (approx. $80 \%$ ) of stage 2 iNKT cells display a $\mathrm{CD} 4^{+} \mathrm{CD} 8{ }^{-}$phenotype and express ThPOK at the highest level among iNKT subsets [16, 29]. We, therefore, examined CD4, CD8, and GFP (i.e., Thpok) expression in MAZR$\mathrm{cKO}^{\mathrm{Lck} / \mathrm{GFP}}$ iNKT cells. Notably, MAZR-cKO ${ }^{\mathrm{Lck} / \mathrm{GFP}}$ mice displayed an increased percentage of $\mathrm{CD}^{+}{ }^{+} \mathrm{CD} 8^{-}$iNKT cells in all analyzed tissues when compared with $\mathrm{WT}^{\mathrm{Lck} / \mathrm{GFP}}$ 


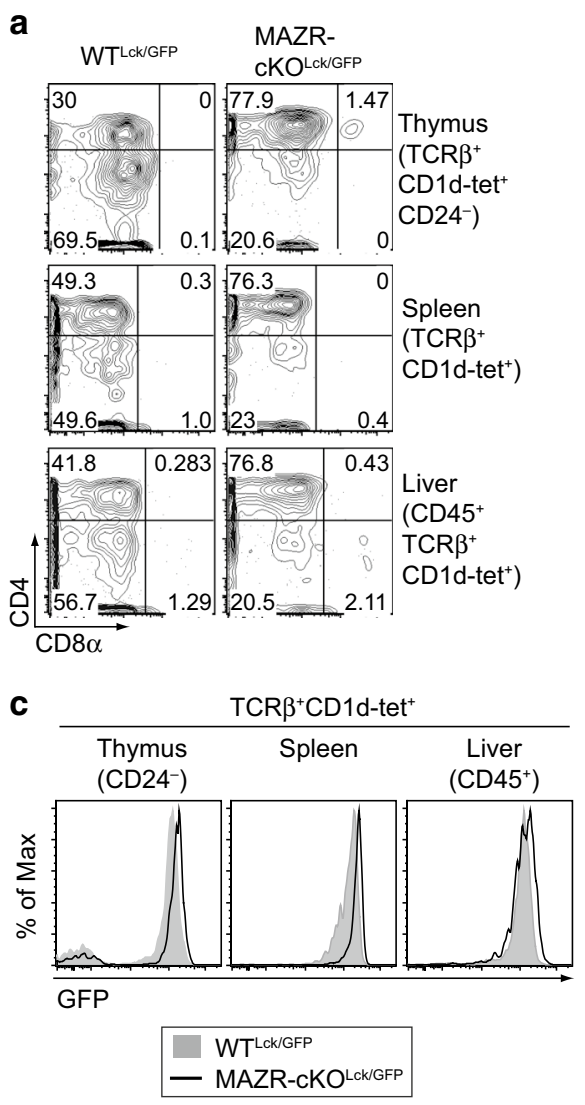

Fig. 2 Deletion of MAZR in $\mathrm{T}$ cells leads to an increased proportion of $\mathrm{CD}^{+} \mathrm{CD}^{-}$iNKT subset and elevated expression of ThPOK in iNKT cells. a Flow cytometry analysis showing CD4 and $\mathrm{CD} 8 \alpha$ expression on $\mathrm{TCR} \beta^{+} \mathrm{CD} 1 \mathrm{~d}-\mathrm{tet}^{+} \mathrm{CD} 24^{-}$thymocytes (upper panel), $\mathrm{TCR} \beta^{+} \mathrm{CD} 1 \mathrm{~d}-$ tet $^{+}$splenocytes (middle panel) and $\mathrm{CD} 45^{+} \mathrm{TCR} \beta^{+} \mathrm{CD} 1 \mathrm{~d}-$ tet $^{+}$hepatic lymphocytes (lower panel) isolated from $\mathrm{WT}^{\mathrm{Lck} / \mathrm{GFP}}$ and MAZR-cKO ${ }^{\mathrm{Lck} / \mathrm{GFP}}$ mice. Numbers indicate the percentages of cells within the respective regions. Data are representative of at least ten mice analyzed in at least five independent experiments (thymocytes and splenocytes), and of eight mice analyzed in 4 independent experiments (hepatic lymphocytes). b Diagrams showing the percentages of $\mathrm{CD} 4^{+} \mathrm{CD} 8 \alpha^{-}$cells within $\mathrm{TCR} \beta^{+} \mathrm{CD} 1 \mathrm{~d}-\mathrm{tet}^{+} \mathrm{CD} 24^{-}$ thymocytes (left panel), TCR $\beta^{+} \mathrm{CD} 1 \mathrm{~d}-\mathrm{tet}^{+}$splenocytes (middle panel) and $\mathrm{CD} 45^{+} \mathrm{TCR} \beta^{+} \mathrm{CD} 1 \mathrm{~d}-$ tet $^{+}$hepatic lymphocytes (right panel) isolated from $\mathrm{WT}^{\mathrm{Lck} / \mathrm{GFP}}$ and MAZR-cKO ${ }^{\mathrm{Lck} / \mathrm{GFP}}$ mice. Each dot represents one mouse. Horizontal bars indicate mean values. c Histograms

mice (Fig. 2a, b). Moreover, the level of GFP (i.e., of Thpok) expression was increased in the absence of MAZR (Fig. 2c, d). Thus, the deletion of MAZR leads to an increase in stage 2 iNKT cells, concurrent with the enhanced expression of CD4 and ThPOK in iNKT cells.

\section{Increased numbers of iNKT2 cells in the absence of MAZR}

According to the "lineage diversification" model, iNKT cells can be categorized into three distinct subsets based on the expression pattern of several transcription factors,
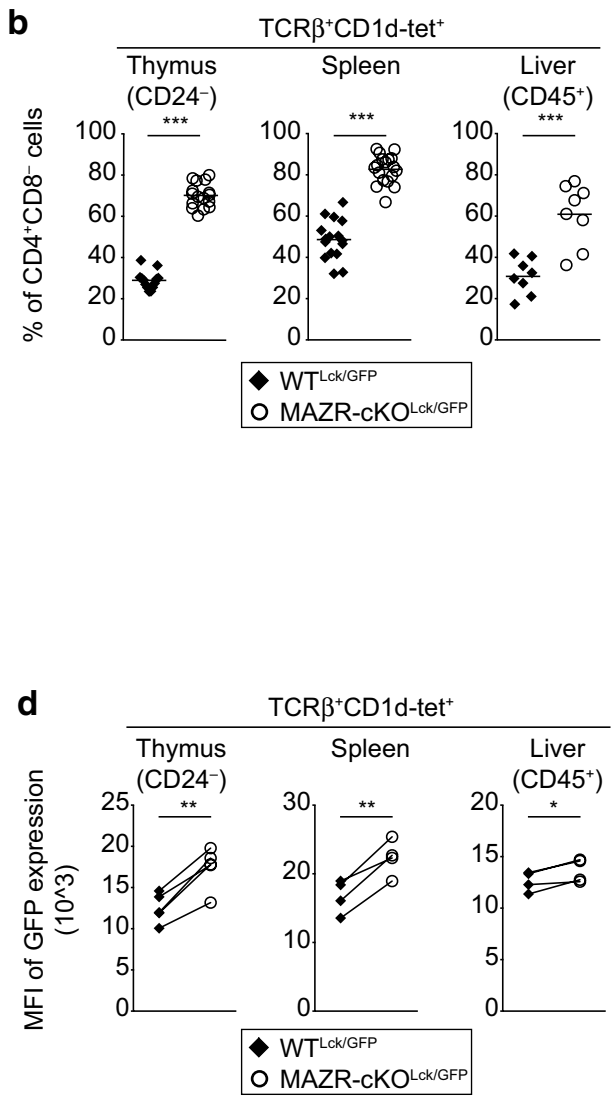

showing GFP expression (i.e., Thpok expression) in $\mathrm{TCR} \beta^{+} \mathrm{CD} 1 \mathrm{~d}-$ tet ${ }^{+} \mathrm{CD} 24^{-}$thymocytes (left panel), TCR $\beta^{+} \mathrm{CD} 1 \mathrm{~d}$-tet ${ }^{+}$splenocytes (middle) and $\mathrm{CD} 45^{+} \mathrm{TCR} \beta^{+} \mathrm{CD} 1 \mathrm{~d}-$ tet $^{+}$hepatic lymphocytes (right) isolated from $\mathrm{WT}^{\mathrm{Lck} / \mathrm{GFP}}$ and MAZR-cKO $\mathrm{L}^{\mathrm{Lck} / \mathrm{GFP}}$ mice. Data are representative of at least ten mice analyzed in at least five independent experiments (thymocytes), and of eight mice analyzed in four independent experiments (splenocytes and hepatic lymphocytes). d Diagrams showing mean fluorescent intensity (MFI) of GFP expression in $\mathrm{TCR} \beta^{+} \mathrm{CD} 1 \mathrm{~d}-$ tet $^{+} \mathrm{CD} 24^{-}$thymocytes (left panel), TCR $\beta^{+} \mathrm{CD} 1 \mathrm{~d}-$ tet $^{+}$splenocytes (middle panel), and CD $45^{+} \mathrm{TCR} \beta^{+} \mathrm{CD} 1 \mathrm{~d}-$ tet $^{+}$hepatic lymphocytes (right panel) isolated from $\mathrm{WT}^{\mathrm{Lck} / \mathrm{GFP}}$ and MAZR$\mathrm{cKO}^{\mathrm{Lck} / \mathrm{GFP}}$ mice. Each dot represents the average value of an individual experiment, in which 2-3 mice were analyzed per group. The lines indicate paired experiments. A paired two-tailed Student's $t$ test was performed for statistical analysis

including T-bet, PLZF and ROR $\gamma$ t; iNKT1 (T-bet ${ }^{\mathrm{hi}} \mathrm{PLZF}^{\mathrm{lo}}$ ), iNKT2 (PLZF ${ }^{\text {hi }}$ ROR $\gamma \mathrm{t}^{-}$) and iNKT17 $\left(\mathrm{PLZF}^{\mathrm{mid}} \mathrm{ROR} \gamma \mathrm{t}^{+}\right)$ cells [15]. Since the deletion of MAZR led to an increase in stage 2 iNKT subsets, which includes iNKT2 and iNKT17 cells [15], we assessed the expression pattern of these signature transcription factors in MAZR-cKO ${ }^{\mathrm{Lck} / \mathrm{GFP}}$ iNKT cells. This revealed that the percentage and numbers of iNKT2 cells in the thymus and spleen were increased in the absence of MAZR, accompanied with a reduction in the number of splenic iNKT1 and iNKT17 cells in MAZR$\mathrm{cKO}^{\text {Lck/GFP }}$ mice (Fig. 3a, b; Fig. S2a, S2b). In addition to the PLZF ${ }^{\text {hi }}{ }^{\text {ROR } \gamma t^{-}}$expression phenotype, iNKT2 cells are 


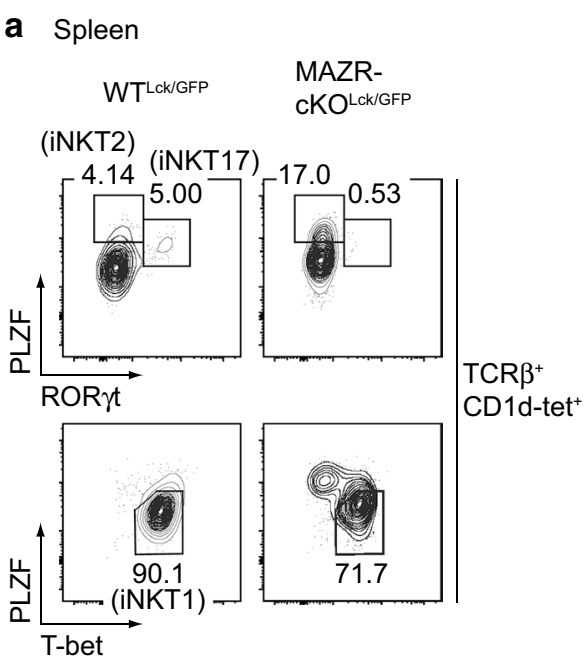

Fig. 3 Distribution of iNKT cell subsets is altered in the absence of MAZR. a Flow cytometry analysis showing PLZF and ROR $\gamma \mathrm{t}$ expression (upper panel) and PLZF and T-bet expression (lower panel) in TCR $\beta^{+}$CD1d-tet ${ }^{+}$splenocytes isolated from WT $\mathrm{Wck}^{\mathrm{LcFP}}$ and MAZR-cKO ${ }^{\mathrm{Lck} / \mathrm{GFP}}$ mice. Numbers indicate the percentages of splenic T-bet ${ }^{\text {hi }}$ PLZF $^{\text {lo }}$ iNKT1, PLZF ${ }^{\text {hi }}$ ROR $\gamma \mathrm{t}^{-}$iNKT2, and PLZF ${ }^{\text {mid }}$ ROR $\gamma \mathrm{t}^{+}$

also characterized by the expression of several surface markers including CD4, CD27, and IL-17RB as well as the transcription factor GATA-binding protein 3 (GATA3) $[15,16]$. MAZR-cKO ${ }^{\text {Lck/GFP }}$ iNKT2 cells expressed all of those markers at similar levels in comparison with $\mathrm{WT}^{\mathrm{LCK} / \mathrm{GFP}}$ iNKT2 cells (Fig. S3a, S3b). These data suggest that the increase in stage 2 iNKT subsets in the absence of MAZR was due to enhanced iNKT2 cell differentiation. Furthermore, these results indicate that MAZR negatively regulates iNKT2 cell differentiation and that MAZR is required for splenic iNKT1 and iNKT17 cell differentiation.

\section{iNKT cell-intrinsic alterations in the absence of MAZR}

The $L c k$-Cre strain initiates deletion at the DN2 to DN3 transition of thymocyte development [38], and MAZR is thereby deleted in all T-cell subsets beyond this developmental stage. It is, therefore, possible that the increase in iNKT2 cells in MAZR-cKO ${ }^{\mathrm{Lck} / \mathrm{GFP}}$ mice is due to alterations in noniNKT T-cell subsets that lead to changes in iNKT cells. To determine whether loss of MAZR led to iNKT cell-intrinsic changes, competitive bone-marrow (BM) reconstitution experiments were performed. For this, $\mathrm{WT}^{\mathrm{Lck} / \mathrm{GFP}}\left(\mathrm{CD} 45.2^{+}\right)$ or MAZR-cKO ${ }^{\mathrm{Lck} / \mathrm{GFP}}\left(\mathrm{CD} 45.2^{+}\right) \mathrm{BM}$ cells were mixed with congenic $\left(\mathrm{CD} 45.1^{+}\right) \mathrm{WT}$ BM cells at a 1:1 ratio and injected into lethally irradiated CD45.1 ${ }^{+}$mice. $8-10$ weeks later, thymic and splenic iNKT cell subsets in reconstituted BM

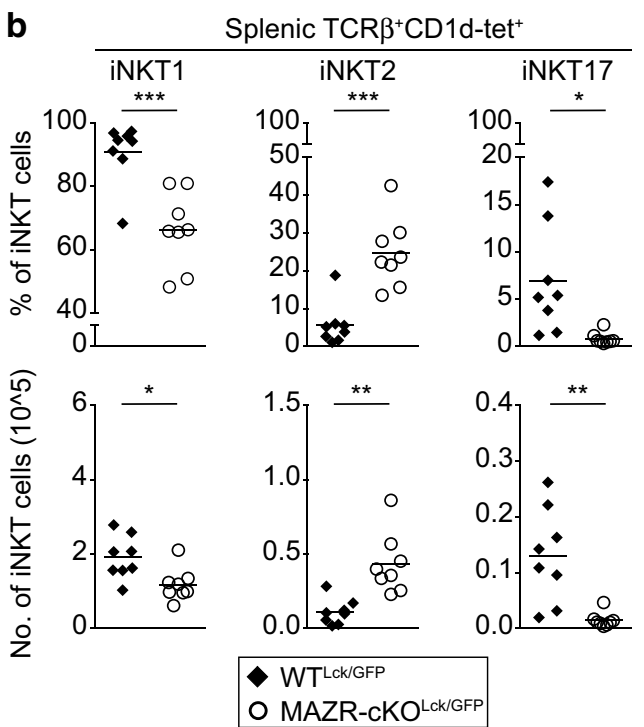

iNKT17 cells. Data are representative of eight mice analyzed in four independent experiments. b Diagrams showing the percentages (upper panel) and numbers (lower panel) of splenic iNKT1 (left panel), iNKT2 (middle panel) and iNKT17 (right panel) cells in $\mathrm{WT}^{\mathrm{Lck} / \mathrm{GFP}}$ and MAZR-cKO ${ }^{\mathrm{Lck} / \mathrm{GFP}}$ mice. Each dot represents one mouse. Horizontal bars indicate mean values

chimeric mice were analyzed (Fig. S4a). Similar to the phenotype observed in MAZR-cKO ${ }^{\mathrm{Lck} / \mathrm{GFP}}$ mice, splenic iNKT cells in the MAZR-cKO ${ }^{\mathrm{Lck} / \mathrm{GFP}}$ compartment of BM chimeric mice displayed an increased fraction of iNKT2 cells, with a corresponding reduction in the percentage of the other subsets [although the difference in iNKT17 cell percentage between $\mathrm{WT}^{\mathrm{Lck} / \mathrm{GFP}}$ and MAZR-cKO ${ }^{\mathrm{Lck} / \mathrm{GFP}}$ compartments reached statistical significance $(p=0.0298)$ only with an unpaired two-tailed Student's $t$ test] (Fig. 4a, b). In addition, there was also a tendency that thymic MAZR-deficient iNKT2 subsets were enhanced in BM chimeric mice (Fig. $\mathrm{S} 4 \mathrm{~b}, \mathrm{~S} 4 \mathrm{c})$. Together, these results suggest that the alterations in the distribution of iNKT subsets in MAZR-cKO ${ }^{\mathrm{Lck} / \mathrm{GFP}}$ are due to iNKT cell-intrinsic defects.

\section{Deletion of MAZR leads to alterations in iNKT cell cytokine expression}

iNKT cells rapidly produce various cytokines upon stimulation $[4,20]$. iNKT2 and iNKT17 cells mainly secrete IL-4 and IL-17A, respectively, whereas iNKT1 cells produce both IFN- $\gamma$ and IL-4 [15]. To determine cytokine production in the absence of MAZR, we activated thymic and splenic iNKT cells isolated from $\mathrm{WT}^{\mathrm{Lck} / \mathrm{GFP}}$ and MAZR-cKO ${ }^{\mathrm{Lck} / \mathrm{GFP}}$ mice with PMA/ionomycin and measured IFN- $\gamma$, IL-4, and IL-17A expression by intracellular staining. In agreement with the increase in iNKT2 subsets in the absence of MAZR, the MAZR-cKO ${ }^{\mathrm{Lck} / G F P}$ iNKT cell 
a Spleen

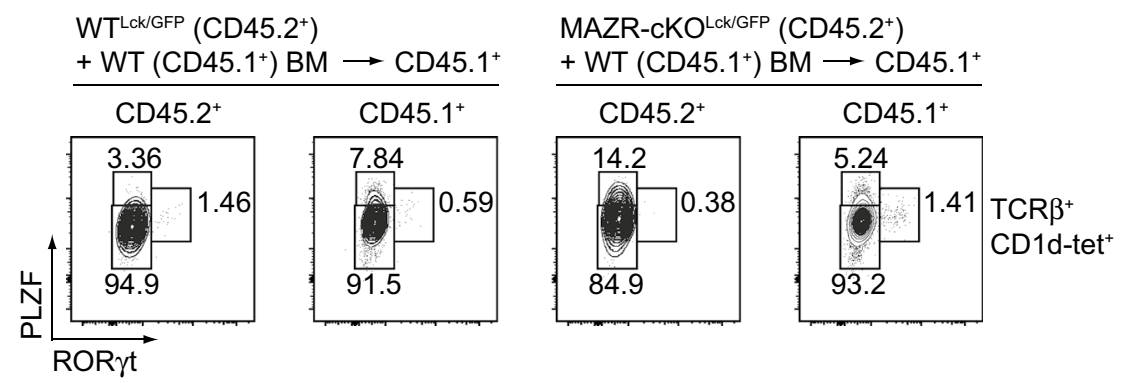

b

Splenic TCR $\beta^{+}$CD1d-tet ${ }^{+}$

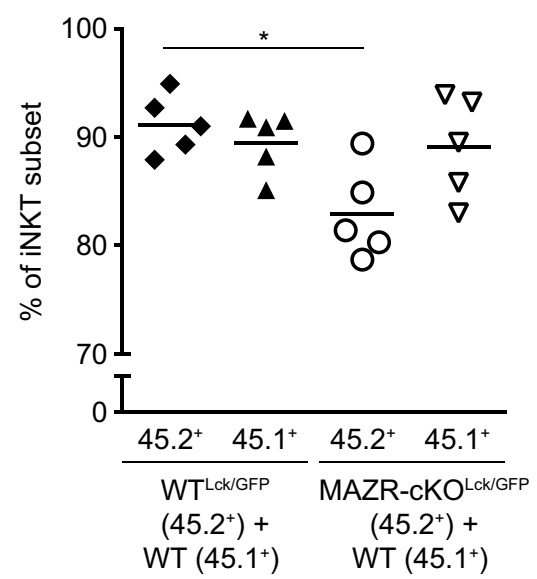

PLZFiROR $\gamma$ t $^{\text {iNKT2 }}$

PLZF ${ }^{\text {mid }}$ ROR $\gamma \mathrm{t}^{+}$iNKT17
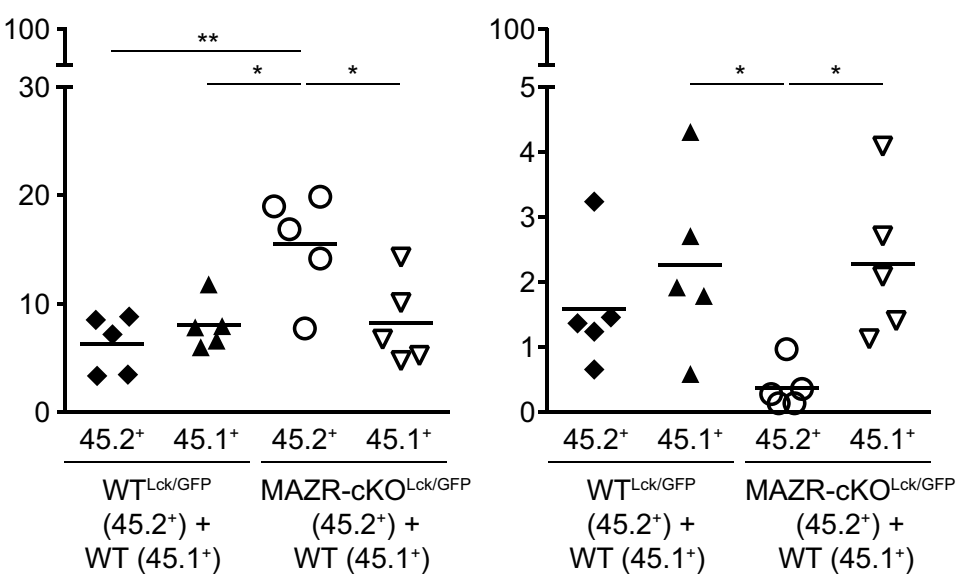

Fig. 4 Altered iNKT cell development by loss of MAZR is due to iNKT cell-intrinsic defects. a Flow cytometry analysis showing PLZF and ROR $\gamma \mathrm{t}$ expression in CD45.2 ${ }^{+}$and CD45.1 $1^{+}$subsets of $\mathrm{TCR} \beta^{+} \mathrm{CD} 1 \mathrm{~d}-$ tet $^{+}$splenocytes isolated from BM chimeric CD45.1 $1^{+}$ mice. $\mathrm{CD} 45.1^{+}$recipient mice received either $\mathrm{WT}^{\mathrm{Lck} / \mathrm{GFP}}\left(\mathrm{CD} 45.2^{+}\right)$ or MAZR-cKO ${ }^{\mathrm{Lck} / \mathrm{GFP}}\left(\mathrm{CD} 45.2^{+}\right) \mathrm{BM}$ cells that had been mixed at a $1: 1$ ratio with wild-type $\left(\mathrm{WT}, \mathrm{CD} 45.1^{+}\right) \mathrm{BM}$ cells. Data are representative of five mice analyzed in two independent experiments. b Diagram showing the percentage of splenic PLZF ${ }^{\mathrm{lo}} \mathrm{ROR} \gamma \mathrm{t}^{-}$non-

population contained a higher percentage of IL-4-producing cells compared to the $\mathrm{WT}^{\mathrm{Lck} / \mathrm{GFP}}$ iNKT cell population (Fig. 5a, b; Fig. S5a, S5b). In addition, splenic iNKT cells produced less IL-17A (Fig. 5a, b), which is also consistent with the observed reduction of splenic iNKT17 cell numbers in the absence of MAZR (Fig. 3). Of note, the analysis of cytokine production in NK1.1 ${ }^{+}$iNKT cells revealed that the proportion of IFN- $\gamma^{+}$cells was increased in the absence of MAZR (Fig. S5c, S5d). This suggests that MAZR-cKO ${ }^{\mathrm{Lck} / \mathrm{GFP}}$ iNKT1 cells express a higher amount of IFN- $\gamma$ despite the reduction in their number. Next, we assessed cytokine production of MAZR-deficient iNKT cells upon in vivo stimulation. Therefore, $\alpha$-GalCer was injected intravenously into $\mathrm{WT}^{\mathrm{Lck} / \mathrm{GFP}}$ and MAZR$\mathrm{cKO}^{\mathrm{Lck} / \mathrm{GFP}}$ mice and cytokine production of splenic and

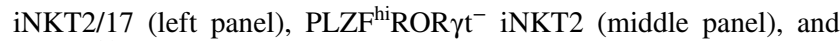
PLZF $^{\text {mid }}{ }^{R O R} \gamma \mathrm{t}^{+}{ }^{\text {iNKT17 (right panel) cells within CD45.2 }}{ }^{+}\left(45.2^{+}\right)$ and $\mathrm{CD} 45.1^{+}\left(45.1^{+}\right)$subsets of $\mathrm{TCR} \beta^{+} \mathrm{CD} 1 \mathrm{~d}-$ tet $^{+}$splenocytes isolated from $\mathrm{BM}$ chimeric $\mathrm{CD} 45.1^{+}$mice generated as described in $\mathbf{a}$. Each dot represents one mouse. Horizontal bars indicate mean values. A one-way ANOVA followed by Tukey multiple comparison test was used for statistical analysis. Differences that did not reach a statistically significant level (i.e., $p \geq 0.05$ ) are not indicated

hepatic iNKT cells was determined 90 min post-injection. In line with our findings in in vitro PMA/ionomycin-stimulated iNKT cells (Fig. 5a, b), splenic and hepatic MAZR$\mathrm{cKO}^{\mathrm{Lck} / \mathrm{GFP}}$ iNKT cells from mice receiving $\alpha$-GalCer produced more IL-4, while IL-17A production was reduced in comparison with WT ${ }^{\text {Lck/GFP }}$ iNKT cells (Fig. 5c-f). Moreover, there was a tendency $(p=0.0911)$ that the proportion of IFN- $\gamma^{+}$cells in splenic MAZR-cKO ${ }^{\text {Lck/GFP }}$ iNKT cells was increased. This is consistent with an increased IFN- $\gamma$ production in NK1.1 $1^{+}$MAZR-cKO ${ }^{\mathrm{Lck} / \mathrm{GFP}}$ iNKT cells in vitro (Fig. S5c, S5d), since intravenous $\alpha$-GalCer injection was shown to preferentially activate iNKT1 cells in the spleen [39]. Together, these data suggest that MAZR is required for the proper regulation of cytokine production in iNKT cells both upon in vitro and in vivo stimulation. 


\section{Increased Egr2 expression during iNKT cell development by loss of MAZR}

During positive selection, a strong TCR signal induces high-level expression of Egr2 in iNKT cell precursors [7]. Subsequently, Egr2 initiates the acquisition of effector properties via directly inducing PLZF expression, whereas the proliferative expansion of iNKT cell precursors is mediated by c-myc [7-11]. Previous studies have demonstrated that subtle changes in Egr2 and PLZF expression levels during the course of iNKT cell development have profound impact on iNKT cell subset differentiation $[34,40]$. To examine whether MAZR regulates iNKT cell subset differentiation through the regulation of Egr2, c-myc and PLZF expression, we analyzed the expression of these molecules at each developmental stage of MAZR-cKO ${ }^{\mathrm{Lck} / \mathrm{GFP}}$ iNKT cells. The deletion of MAZR led to an increase in Egr2 expression at stage 2 and 3 iNKT cells in comparison with WT cells, whereas there was no alteration in c-myc expression in MAZR-cKO ${ }^{\text {Lck/GFP }}$ cells (Fig. 6a-d). In addition, stage 2 MAZR-cKO ${ }^{\text {Lck/GFP }}$ iNKT cells displayed enhanced PLZF expression compared to the corresponding $\mathrm{WT}^{\mathrm{Lck} / \mathrm{GFP}}$ iNKT cell subset, most likely due to the enlargement of the iNKT2 cell subset (Fig. 6e-g). However, despite the increase in Egr2 expression in stage 3 MAZR-cKO ${ }^{\text {Lck/GFP }}$ iNKT cells, there was no alteration in the expression level of PLZF in the cells (Fig. 6e, f). Thus, these data suggest that MAZR negatively regulates Egr2 expression at stage 2 and stage 3 of iNKT cell development.

\section{Discussion}

In this study, we investigated the role of the transcription factor MAZR in the development and effector function of iNKT cells. We observed an increase in the number of thymic and splenic iNKT2 cells in MAZR-cKO ${ }^{\text {Lck/GFP }}$ mice, while splenic iNKT1 and iNKT17 cells were reduced. Moreover, $\mathrm{BM}$ reconstitution experiments indicated that the alteration in iNKT cell development in the absence of MAZR occurred in an iNKT cell-intrinsic manner. The increase in iNKT2 cells was also accompanied with elevated CD4, ThPOK, and Egr2 expression in MAZR-cKO ${ }^{\mathrm{Lck} / \mathrm{GFP}}$ iNKT cells, indicating that MAZR regulates ThPOK and CD4 expression not only in conventional $\mathrm{T}$ cells $[24,25]$, but also in iNKT cells. Thus, our data demonstrate an important role of MAZR for the regulation of iNKT cell development and subset differentiation. It is unlikely that the alterations in the distribution of iNKT cell subsets observed in MAZR-cKO ${ }^{\mathrm{Lck} / \mathrm{GFP}}$ mice were due to changes in the survival and/or proliferation of particular iNKT cell subsets, since there was no difference in the proportion of Annexin $\mathrm{V}^{+}$cells or BrdU incorporating cells at the various classical CD44/NK1.1 developmental stages of iNKT cells (Fig. S6). A normal incorporation of BrdU is also in line with our data showing that there is no change in the expression of c-myc, known to be important for iNKT cell proliferation [10, 11], in MAZR-deficient iNKT cells. We, therefore, rather conclude that MAZR controls iNKT cell subset differentiation via regulating iNKT cell subset fate decisions and/or the subsequent differentiation processes of iNKT cell subsets.

Consistent with the alteration in iNKT cell subset differentiation, MAZR-deficient iNKT cells displayed enhanced production of IL-4, along with a reduction in IL-17A production. This was also observed upon injection of $\alpha$-GalCer, which is a well-established model of acute hepatitis [41, 42]. Since IL-4 and IL-17A produced by iNKT cells have detrimental as well as protective functions in this model, respectively [43, 44], we also studied whether the observed changes in cytokine production lead to hepatic damage in $\mathrm{WT}^{\mathrm{Lck} / \mathrm{GFP}}$ and MAZR-cKO ${ }^{\mathrm{Lck} / \mathrm{GFP}}$ mice. However, serum levels of alanine aminotransferase (ALT) and aspartate aminotransferase (AST) in MAZR-cKO ${ }^{\text {Lck/GFP }}$ mice were comparable to those in $\mathrm{WT}^{\mathrm{Lck} / \mathrm{GFP}}$ mice (Fig. S7), suggesting that MAZR deficiency in T cells had no impact on $\alpha$-GalCermediated acute hepatitis. Activated iNKT cells induce liver injury not only by secreting a broad spectrum of cytokines, but also via cytolytic proteins and through killer activation receptors $[45,46]$. Thus, changes in some of these other mechanisms might compensate for alterations in cytokine expression upon loss of MAZR, thereby leading to a similar extent of liver injury as observed in $\mathrm{WT}^{\mathrm{Lck} / \mathrm{GFP}}$ mice.

In this study, we showed that MAZR negatively regulates Egr2 expression in stage 2 and 3 iNKT cells. Egr2 is induced upon the engagement of iNKT TCRs with glycolipid-loaded CD1d molecules, and initiates the acquisition of effector properties by directly inducing PLZF expression [7-9]. Moreover, recent studies showed that the modulation of TCR-signaling strength leads to alterations in iNKT cell subset differentiation, accompanied with changes in Egr2 expression levels in stage 1-3 iNKT cells [34, 47]. Since iNKT2 cells express the highest level of Egr2 followed by iNKT17 and iNKT1 cells [34], the increase in Egr2 expression in stage 2 MAZR-cKO ${ }^{\text {Lck/GFP }}$ iNKT cells might be due the enlargement of iNKT2 cell subset in the absence of MAZR. However, Egr2 expression was also increased in stage 3 MAZR-cKO ${ }^{\text {Lck/GFP }}$ iNKT cells, suggesting that MAZR is rather required to restrict Egr2 expression below a certain threshold level in stage 2 and stage 3 iNKT cells. Given the different expression levels of Egr2 among the three iNKT cell subsets, it might be conceivable that a finetuning of Egr 2 expression levels by MAZR plays an important role for appropriate iNKT cell subset differentiation. Of note, MAZR protein is expressed at the highest level in stage 0 iNKT cells, and its expression levels are gradually downmodulated at the subsequent developmental stages 
a Spleen (in vitro PMA/ionomycin)
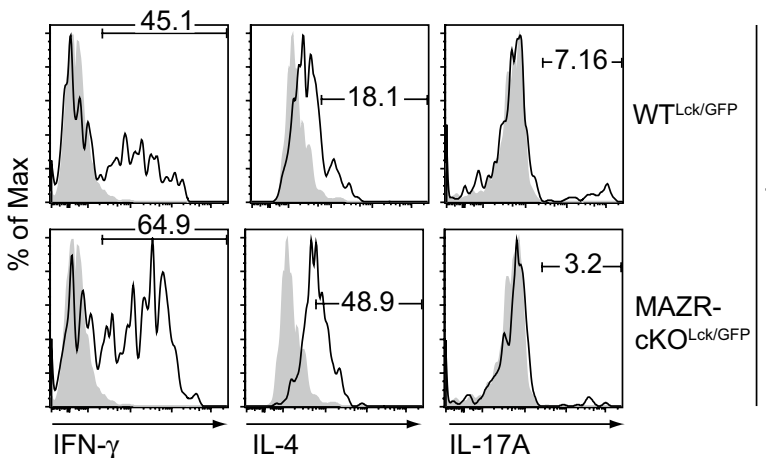

C
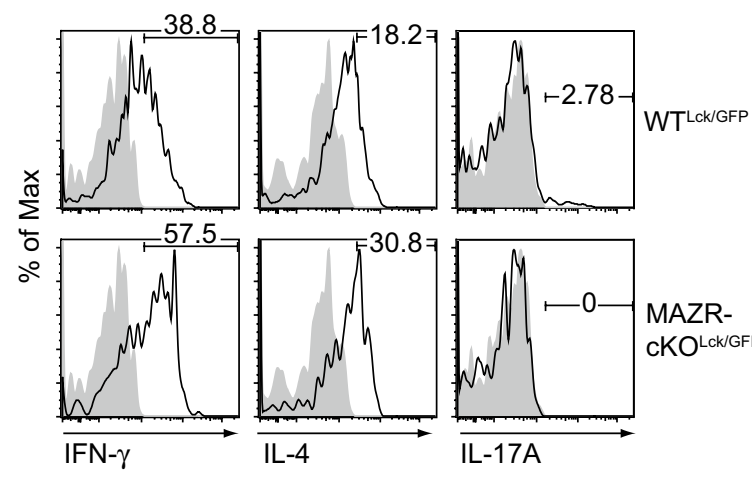

e

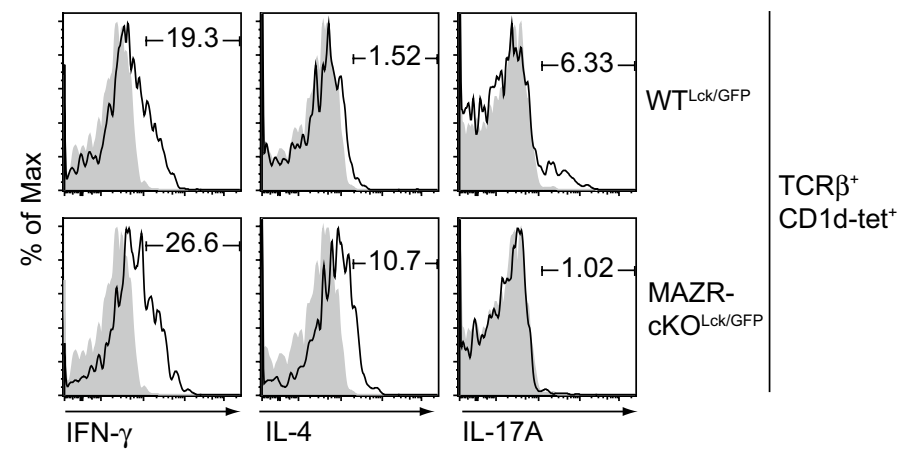

b

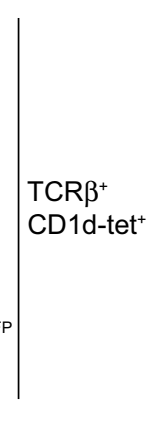

d

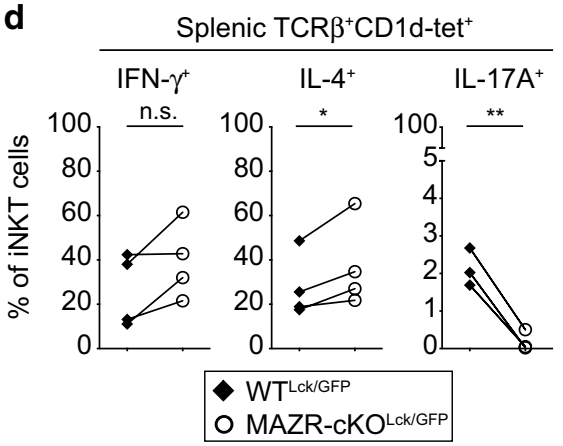

f

Hepatic TCR $\beta^{+}$CD1d-tet ${ }^{+}$

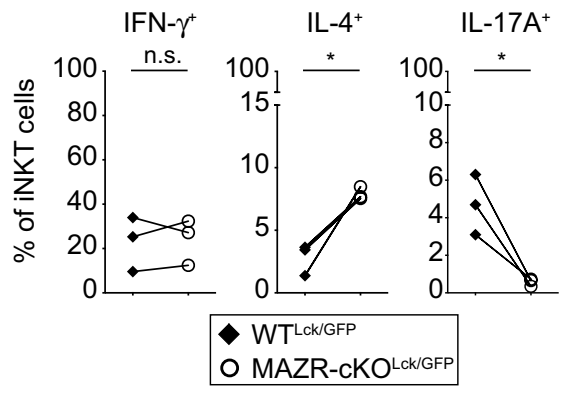

(Fig. S8). Therefore, despite its rather low expression level, MAZR negatively regulates Egr2 expression at stage 2 and stage 3 iNKT cells. Further studies are required to address the mechanisms by which MAZR regulates Egr2 expression in iNKT cells and the impact of MAZR on developmental processes downstream of Egr2.

We previously demonstrated that MAZR is essential for the establishment and maintenance of ThPOK repression in MHC class I-signaled DP thymocytes and mature $\mathrm{CD}^{+} \mathrm{T}$ cells $[24,25]$. Moreover, MAZR interacts with Runx proteins (i.e., Runx 1 and Runx3) and cooperatively repress ThPOK during T-cell development [25]. In this study, we showed that MAZR controls ThPOK expression also in iNKT cells. Besides its role as key transcription factor for $\mathrm{CD}^{+}{ }^{+} \mathrm{T}$-cell commitment and lineage stability [48-51], ThPOK is also essential for proper iNKT cell subset differentiation [28-31]. In ThPOK-deficient mice, iNKT17 cells are increased, while iNKT2 cells are reduced [28, 29, 31]. Moreover, whereas WT iNKT cells do not express CD8, the deletion of ThPOK leads to the appearance of atypical $\mathrm{CD} 4^{-} \mathrm{CD} 8^{+}$iNKT cells, concurrent with a complete loss of $\mathrm{CD} 4^{+} \mathrm{CD} 8^{-}$subsets $[28,30$, 31]. In contrast to the phenotype upon loss of ThPOK, we observed that iNKT2 cell differentiation was promoted in the absence of MAZR, which was accompanied with the inhibition of iNKT1 and iNKT17 cell differentiation. 
४Fig. 5 MAZR-deficient iNKT cells display altered cytokine production. a Histograms showing IFN- $\gamma$ (left panel), IL-4 (middle panel), and IL-17A (right panel) expression in $\mathrm{TCR} \beta^{+} \mathrm{CD} 1 \mathrm{~d}-\mathrm{tet}^{+}$splenocytes isolated from $\mathrm{WT}^{\mathrm{Lck} / \mathrm{GFP}}$ (upper panel) and MAZR-cKO ${ }^{\mathrm{Lck} / \mathrm{GFP}}$ (lower panel) mice. Splenocytes were stimulated with PMA and ionomycin for $4.5 \mathrm{~h}$ in the presence of GolgiStop. Filled histograms show the expression level of each cytokine in unstimulated $\mathrm{WT}^{\mathrm{Lck} / \mathrm{GFP}}$ TCR $\beta^{+}$CD1d-tet ${ }^{+}$splenocytes. Numbers indicate the percentages of cells within the respective regions. Data are representative of more than ten mice analyzed in at least five independent experiments. b Diagrams showing the percentage of IFN- $\gamma^{+}$(left panel), IL- $4^{+}$(middle panel), and $\mathrm{IL}-17 \mathrm{~A}^{+}$(right panel) PMA/ionomycin-stimulated splenic iNKT cells isolated from WT $\mathrm{W}^{\mathrm{Lck} / \mathrm{GFP}}$ and MAZR-cKO ${ }^{\mathrm{Lck} / \mathrm{GFP}}$ mice. c Histograms showing IFN- $\gamma$ (left panel), IL-4 (middle panel), and IL-17A (right panel) expression in TCR $\beta^{+} \mathrm{CD} 1 \mathrm{~d}-$ tet $^{+}$splenocytes isolated from $\alpha$-GalCer-treated $\mathrm{WT}^{\mathrm{Lck} / \mathrm{GFP}}$ (upper panel) and MAZR$\mathrm{cKO}^{\mathrm{Lck} / \mathrm{GFP}}$ (lower panel) mice. Filled histograms show the expression level of each cytokine in splenic iNKT cells from vehicle-treated $\mathrm{WT}^{\mathrm{Lck} / \mathrm{GFP}}$ mice. d Diagrams showing the percentage of IFN- $\gamma^{+}$(left panel), IL-4 ${ }^{+}$(middle panel), and $\mathrm{IL}_{-17 \mathrm{~A}^{+}}$(right panel) splenic iNKT cells isolated from $\alpha$-GalCer-treated $\mathrm{WT}^{\mathrm{Lck} / \mathrm{GFP}}$ and MAZR$\mathrm{cKO}^{\mathrm{Lck} / \mathrm{GFP}}$ mice. e Histograms showing IFN- $\gamma$ (left panel), IL-4 (middle panel), and IL-17A (right panel) expression in TCR $\beta^{+} \mathrm{CD} 1 \mathrm{~d}-$ tet $^{+}$hepatic lymphocytes isolated from $\alpha$-GalCer-treated WT ${ }^{\text {Lck/GFP }}$ (upper panel) and MAZR-cKO ${ }^{\mathrm{Lck} / \mathrm{GFP}}$ (lower panel) mice. Filled histograms show the expression level of each cytokine in hepatic iNKT cells from vehicle-treated WT ${ }^{\text {Lck/GFP }}$ mice. f Diagrams showing the percentage of IFN- $\gamma^{+}$(left panel), IL- $4^{+}$(middle panel), and IL$17 \mathrm{~A}^{+}$(right panel) hepatic iNKT cells isolated from $\alpha$-GalCer-treated $\mathrm{WT}^{\mathrm{Lck} / \mathrm{GFP}}$ and MAZR-cKO ${ }^{\mathrm{Lck} / \mathrm{GFP}}$ mice. c, e Splenocytes and hepatic lymphocytes were isolated $1.5 \mathrm{~h}$ after $\alpha$-GalCer administration, and were stained for intracellular cytokines after incubation with GolgiStop and GolgiPlug. Numbers indicate the percentages within the respective quadrants. Data are representative of 6-7 mice analyzed in 3-4 independent experiments. b, d, f Each dot represents the average value of an individual experiment, in which 1-3 mice were analyzed per group. The lines indicate paired experiments. A paired two-tailed Student's $t$ test was performed for statistical analysis

Furthermore, there was also an increase in the proportion of $\mathrm{CD}^{+} \mathrm{CD}^{-}$iNKT cell subsets. Together, these data suggest antagonistic functions for ThPOK and MAZR during iNKT cell development. iNKT2 and iNKT17 cells express ThPOK at the highest and lowest levels among the three subsets, respectively [29]. Given that enforced ThPOK expression in iNKT cells led to the repression of ROR $\gamma t$, fine-tuning of ThPOK expression might be essential for appropriate iNKT cell subset differentiation, particularly for iNKT17 cell development [29, 31]. Thus, it is conceivable that the increase in ThPOK expression in MAZR-deficient iNKT cells contributes to the alteration in iNKT cell subset distribution. Since MAZR acts in synergy with Runx 3 to repress ThPOK expression during CD ${ }^{+}$T-cell development [25], we also examined whether there is synergistic activity in the regulation of iNKT cell development by analyzing MAZR/Runx3 double-mutant mice (on a $C d 4$-Cre background) [25]. The combined deletion of MAZR and Runx3 led to a reduction of thymic iNKT cell numbers, and a similar tendency was also observed in Runx3 single-mutant mice (Fig. S9a,
S9b). Notably, MAZR/Runx3 double-mutant iNKT cells expressed ThPOK at a higher level than WT control cells, and also showed a tendency of increased ThPOK expression compared to MAZR and Runx3 single-mutant cells $(p=0.0371$ and 0.0494 , respectively, with an unpaired two-tailed Student's $t$ test) (Fig S9c, S9d). Moreover, the combined loss of MAZR and Runx3 led to an increase in the percentage of iNKT2 cells, concurrent with a reduced percentage of iNKT17 cells (Fig. S9e, S9f). Together, these data indicate that MAZR and Runx3 synergistically repress ThPOK expression during iNKT cell development, thereby regulating iNKT cell subset differentiation. Therefore, we hypothesize that MAZR controls iNKT cell development through the regulation of Egr2 as well as ThPOK expression. However, it remains to be determined whether these two regulatory processes are connected with each other during iNKT cell development or whether these are two independent regulatory pathways. Further studies are required to elucidate how MAZR is integrated in the transcriptional program controlling iNKT cell subset differentiation, including whether MAZR-mediated fine-tuning of ThPOK expression is part of the processes determining iNKT cell fate.

Finally, we noticed that the alteration in iNKT cell subset differentiation in the absence of MAZR was more evident in the spleen than in the thymus, both under homeostatic conditions in MAZR-cKO ${ }^{\mathrm{Lck} / \mathrm{GFP}}$ mice as well as in competitive bone-marrow (BM) reconstitution experiments. Although the mechanism of peripheral iNKT cell development still remains largely unknown, a recent study has demonstrated that thymic iNKT cell subsets (particularly iNKT1 and iNKT17 cells) are largely tissue-resident and that peripheral iNKT cell subsets derive from a $\mathrm{CCR} 7^{+}$precursor subset of iNKT cells that emigrate from the thymus [52]. It is, therefore, possible that MAZR has a greater impact on iNKT cell subset differentiation in peripheral lymphoid organs compared to the thymus. In addition, the deletion of MAZR might lead to an alteration in the tissue residency of thymic iNKT cell subsets and/or in the homing capacity of mature iNKT cells. Of note, the phenotypic alterations of thymic MAZR-deficient iNKT cells in BM chimeric mice were even milder than the one observed in MAZR-cKO ${ }^{\mathrm{Lck} / \mathrm{GFP}}$ mice. This might be due to a differential impact of MAZR on thymic iNKT cell subset differentiation and/or the tissue residency of thymic iNKT cell subsets under a competitive environment in BM chimeric mice compared to homeostatic condition in MAZR-cKO ${ }^{\mathrm{Lck} / \mathrm{GFP}}$ mice. Further studies are required to address the role of MAZR for thymic iNKT cell development in a competitive BM chimeric setting.

Taken together, our study defines MAZR as an essential transcription factor regulating iNKT cell subset differentiation and effector function. 
a

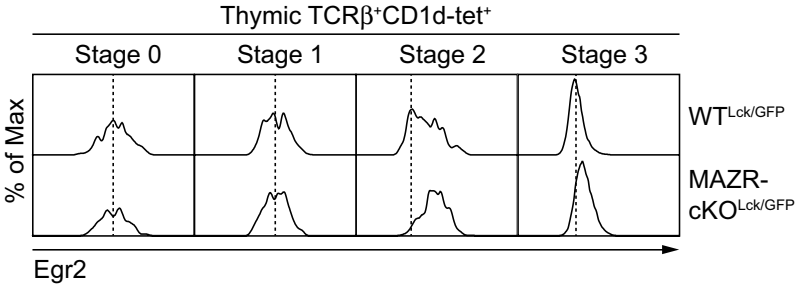

C

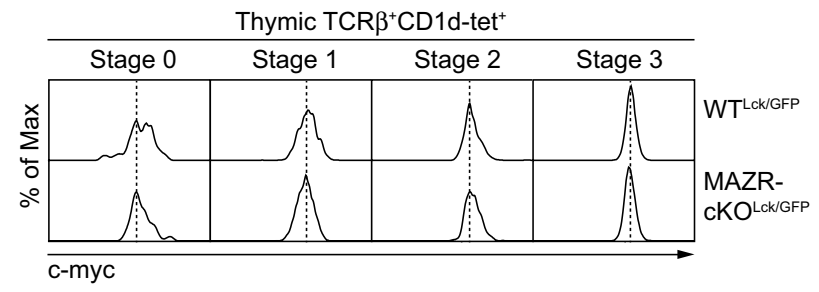

e

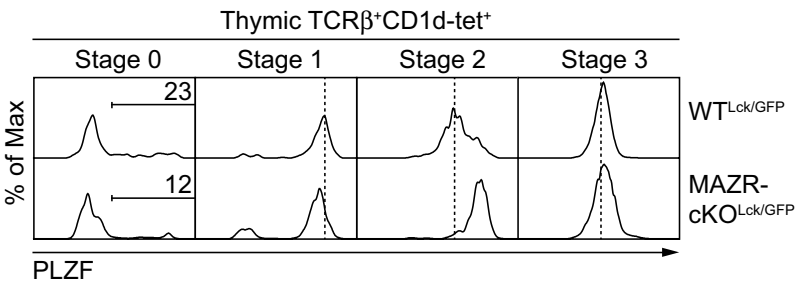

b

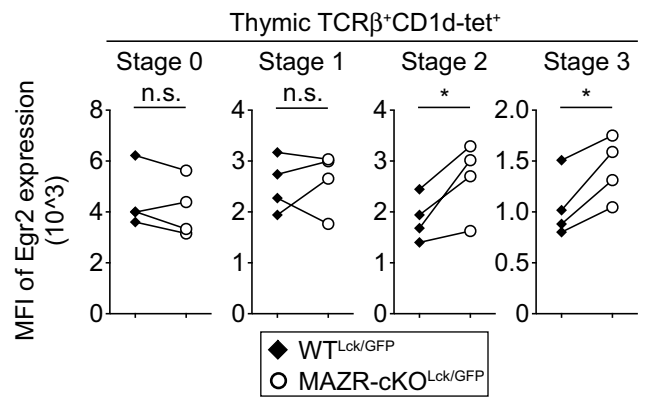

d

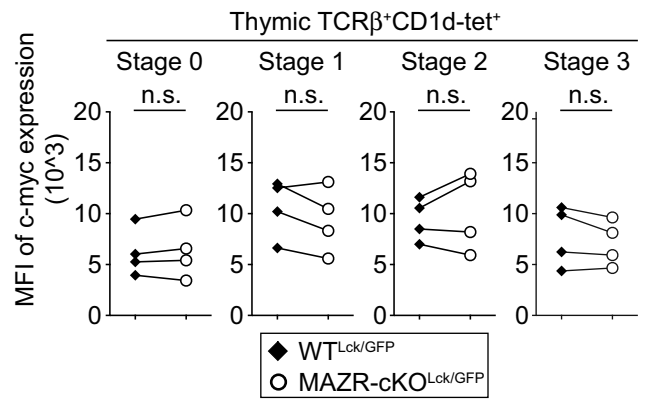

f

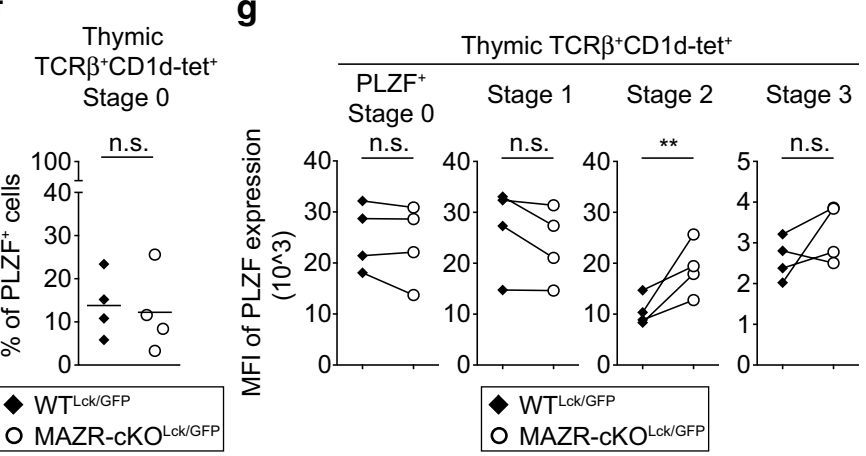

Fig. 6 Enhanced Egr2 expression in thymic MAZR-deficient iNKT cells. a Histograms showing Egr2 expression in thymic stage 0 $\left(\mathrm{CD} 24^{+} \mathrm{CD}_{4} 4^{-} \mathrm{CD} 69^{+}\right)$, stage $1\left(\mathrm{CD} 24^{-} \mathrm{CD} 44^{-} \mathrm{NK} 1.1^{-}\right)$, stage 2 $\left(\mathrm{CD} 24^{-} \mathrm{CD} 44^{+} \mathrm{NK} 1.1^{-}\right)$and stage $3\left(\mathrm{CD} 24^{-} \mathrm{CD} 44^{+} \mathrm{NK} 1.1^{+}\right)$iNKT cells isolated from $\mathrm{WT}^{\mathrm{Lck} / \mathrm{GFP}}$ and MAZR-cKO ${ }^{\mathrm{Lck} / \mathrm{GFP}}$ mice. Dotted lines indicate the peaks of Egr2 expression in WT $\mathrm{Wck}^{\mathrm{Lck} / \mathrm{GFP}} \mathrm{iNKT}$ cells at the individual stages. b Diagrams showing mean fluorescent intensity (MFI) of Egr2 expression in each developmental subset of thymic iNKT cells isolated from $\mathrm{WT}^{\mathrm{Lck} / \mathrm{GFP}}$ and MAZR-cKO ${ }^{\mathrm{Lck} / \mathrm{GFP}}$ mice. c Histograms showing c-myc expression in each developmental subset of thymic iNKT cells (identified as described in a) isolated from $\mathrm{WT}^{\mathrm{Lck} / \mathrm{GFP}}$ and MAZR-cKO ${ }^{\mathrm{Lck} / \mathrm{GFP}}$ mice. Dotted lines indicate the peaks of c-myc expression in $\mathrm{WT}^{\mathrm{Lck} / \mathrm{GFP}}$ iNKT cells at the individual stages. d Diagrams showing MFI of c-myc expression in each developmental subset of thymic iNKT cells isolated from $\mathrm{WT}^{\mathrm{Lck} / \mathrm{GFP}}$ and MAZR-cKO ${ }^{\text {Lck/GFP }}$ mice. e Histograms showing PLZF expression in each developmental subset of thymic iNKT cells (identified as described in a) isolated from $\mathrm{WT}^{\mathrm{Lck} / \mathrm{GFP}}$ and MAZR-cKO $\mathrm{O}^{\mathrm{Lck} / \mathrm{GFP}}$ mice. Regions indicate $\mathrm{PLZF}^{+}$cells within stage 0 iNKT cells, and the numbers above show the proportion of the cells. Dotted lines indicate the peaks of PLZF expression in stage $1-3 \mathrm{WT}^{\mathrm{Lck} / \mathrm{GFP}}$ iNKT cells. $\mathbf{f}$ Diagram showing the percentage of $\mathrm{PLZF}^{+}$cells within thymic stage 0 iNKT cells isolated from WT $\mathrm{Wck}^{\mathrm{L} / \mathrm{GFP}}$ and MAZR-cKO $\mathrm{Lck}^{\mathrm{L} / \mathrm{GFP}}$ mice. Each dot represents one mouse. Horizontal bars indicate mean values. g Diagrams showing MFI of PLZF expression in PLZF ${ }^{+}$stage 0 as well as stage $1-3$ thymic iNKT cells isolated from $\mathrm{WT}^{\mathrm{Lck} / \mathrm{GFP}}$ and MAZR-cKO ${ }^{\mathrm{Lck} / \mathrm{GFP}}$ mice. a, c, e Data are representative of four mice analyzed in four independent experiments. $\mathbf{b}, \mathbf{d}, \mathbf{g}$ Each dot represents one mouse. The lines indicate paired experiments. A paired twotailed Student's $t$ test was performed for statistical analysis
Acknowledgements Open access funding provided by Austrian Science Fund (FWF). We thank the NIH Tetramer Facility for providing PBS57-loaded and unloaded CD1d-tetramers, I. Taniuchi (RIKEN Center for Integrative Medical Sciences (IMS-RCAI), Yokohama, Japan) for providing floxed-Runx3 and Thpok-GFP knock-in mutant mice, I. Engel and M. Kronenberg (La Jolla Institute for Allergy and
Immunology, La Jolla, USA) for technical advice, and Dagmar StoiberSakaguchi (Medical University of Vienna, Vienna, Austria) for critical reading of the manuscript. This work benefited from data assembled by the ImmGen consortium. SS was supported by the Austrian Science Fund (FWF) projects: P23669, P26193 and P27747. WE was supported by the Austrian Science Fund (FWF) projects: P23641 and P29790. 
UW was supported by the Austrian Science Fund (FWF) projects: SFB F4612-B28 and MCCA W 1248-B30. Work in the laboratory of MT was supported by the Doctoral Program 'Inflammation and Immunity' (W1212) of the Austrian Science Fund (FWF), and CZ is a Ph.D. student funded by this program.

Author contributions MJO, CT, LA, AFG, and MA performed experiments and analyzed the data; CZ, TS, and MT measured serum biochemistry; UW gave valuable suggestions for revising the manuscript and interpreting the data; WE designed the research and wrote the manuscript; SS designed the research, performed experiments, analyzed the data, and wrote the manuscript. All authors critically revised the article and approved the final version of the manuscript.

\section{Compliance with ethical standards}

Conflict of interest The authors declare that they have no conflict of interest.

Open Access This article is distributed under the terms of the Creative Commons Attribution 4.0 International License (http://creativeco mmons.org/licenses/by/4.0/), which permits unrestricted use, distribution, and reproduction in any medium, provided you give appropriate credit to the original author(s) and the source, provide a link to the Creative Commons license, and indicate if changes were made.

\section{References}

1. Bendelac A, Savage PB, Teyton L (2007) The biology of NKT cells. Annu Rev Immunol 25:297-336. https://doi.org/10.1146/ annurev.immunol.25.022106.141711

2. Godfrey DI, Uldrich AP, McCluskey J, Rossjohn J, Moody DB (2015) The burgeoning family of unconventional $T$ cells. Nat Immunol 16(11):1114-1123. https://doi.org/10.1038/ni.3298

3. Rossjohn J, Pellicci DG, Patel O, Gapin L, Godfrey DI (2012) Recognition of CD1d-restricted antigens by natural killer T cells. Nat Rev Immunol 12(12):845-857. https://doi.org/10.1038/nri33 28

4. Brennan PJ, Brigl M, Brenner MB (2013) Invariant natural killer T cells: an innate activation scheme linked to diverse effector functions. Nat Rev Immunol 13(2):101-117. https://doi.org/10.1038/ nri3369

5. Das R, Sant'Angelo DB, Nichols KE (2010) Transcriptional control of invariant NKT cell development. Immunol Rev 238(1):195-215. https://doi.org/10.1111/j.1600-065X.2010.00962 . $\mathrm{X}$

6. Gapin L (2016) Development of invariant natural killer T cells. Curr Opin Immunol 39:68-74. https://doi.org/10.1016/j. coi.2016.01.001

7. Seiler MP, Mathew R, Liszewski MK, Spooner CJ, Barr K, Meng F, Singh H, Bendelac A (2012) Elevated and sustained expression of the transcription factors Egr1 and Egr2 controls NKT lineage differentiation in response to TCR signaling. Nat Immunol 13(3):264-271. https://doi.org/10.1038/ni.2230

8. Savage AK, Constantinides MG, Han J, Picard D, Martin E, Li B, Lantz O, Bendelac A (2008) The transcription factor PLZF directs the effector program of the NKT cell lineage. Immunity 29(3):391-403. https://doi.org/10.1016/j.immuni.2008.07.011

9. Kovalovsky D, Uche OU, Eladad S, Hobbs RM, Yi W, Alonzo E, Chua K, Eidson M, Kim HJ, Im JS, Pandolfi PP, Sant'Angelo DB (2008) The BTB-zinc finger transcriptional regulator PLZF controls the development of invariant natural killer $\mathrm{T}$ cell effector functions. Nat Immunol 9(9):1055-1064. https://doi.org/10.1038/ ni.1641

10. Dose M, Sleckman BP, Han J, Bredemeyer AL, Bendelac A, Gounari $F$ (2009) Intrathymic proliferation wave essential for Valpha14+ natural killer T cell development depends on c-Myc. Proc Natl Acad Sci USA 106(21):8641-8646. https://doi.org/10.1073/ pnas.0812255106

11. Mycko MP, Ferrero I, Wilson A, Jiang W, Bianchi T, Trumpp A, MacDonald HR (2009) Selective requirement for c-Myc at an early stage of V(alpha)14i NKT cell development. J Immunol 182(8):4641-4648. https://doi.org/10.4049/jimmunol.0803394

12. Benlagha K, Wei DG, Veiga J, Teyton L, Bendelac A (2005) Characterization of the early stages of thymic NKT cell development. J Exp Med 202(4):485-492. https://doi.org/10.1084/jem.20050456

13. Bezbradica JS, Hill T, Stanic AK, Van Kaer L, Joyce S (2005) Commitment toward the natural $\mathrm{T}$ (iNKT) cell lineage occurs at the $\mathrm{CD} 4^{+} 8^{+}$stage of thymic ontogeny. Proc Natl Acad Sci USA 102(14):5114-5119. https://doi.org/10.1073/pnas.0408449102

14. Constantinides MG, Bendelac A (2013) Transcriptional regulation of the NKT cell lineage. Curr Opin Immunol 25(2):161-167. https ://doi.org/10.1016/j.coi.2013.01.003

15. Lee YJ, Holzapfel KL, Zhu J, Jameson SC, Hogquist KA (2013) Steady-state production of IL-4 modulates immunity in mouse strains and is determined by lineage diversity of iNKT cells. Nat Immunol 14(11):1146-1154. https://doi.org/10.1038/ni.2731

16. Watarai H, Sekine-Kondo E, Shigeura T, Motomura Y, Yasuda T, Satoh R, Yoshida H, Kubo M, Kawamoto H, Koseki H, Taniguchi M (2012) Development and function of invariant natural killer T cells producing T(h)2- and T(h)17-cytokines. PLoS Biol 10(2):e1001255. https://doi.org/10.1371/journal.pbio.1001255

17. Engel I, Kronenberg M (2014) Transcriptional control of the development and function of Valpha14i NKT cells. Curr Top Microbiol Immunol 381:51-81. https://doi.org/10.1007/82_2014_375

18. Kwon DI, Lee YJ (2017) Lineage differentiation program of invariant natural killer T cells. Immune Netw 17(6):365-377. https:// doi.org/10.4110/in.2017.17.6.365

19. Kinjo Y, Kitano N, Kronenberg M (2013) The role of invariant natural killer $\mathrm{T}$ cells in microbial immunity. J Infect Chemother 19(4):560-570. https://doi.org/10.1007/s10156-013-0638-1

20. Van Kaer L, Parekh VV, Wu L (2013) Invariant natural killer T cells as sensors and managers of inflammation. Trends Immunol 34(2):50-58. https://doi.org/10.1016/j.it.2012.08.009

21. Ellmeier W, Taniuchi I (2014) The role of BTB-zinc finger transcription factors during $\mathrm{T}$ cell development and in the regulation of T cell-mediated immunity. Curr Top Microbiol Immunol 381:21-49. https://doi.org/10.1007/82_2014_374

22. Beaulieu AM, Sant'Angelo DB (2011) The BTB-ZF family of transcription factors: key regulators of lineage commitment and effector function development in the immune system. J Immunol 187(6):2841-2847. https://doi.org/10.4049/jimmunol.1004006

23. Bilic I, Koesters C, Unger B, Sekimata M, Hertweck A, Maschek R, Wilson CB, Ellmeier W (2006) Negative regulation of CD8 expression via $\mathrm{Cd} 8$ enhancer-mediated recruitment of the zinc finger protein MAZR. Nat Immunol 7(4):392-400. https://doi. org/10.1038/ni1311

24. Sakaguchi S, Hombauer M, Bilic I, Naoe Y, Schebesta A, Taniuchi I, Ellmeier W (2010) The zinc-finger protein MAZR is part of the transcription factor network that controls the CD4 versus CD8 lineage fate of double-positive thymocytes. Nat Immunol 11(5):442-448. https://doi.org/10.1038/ni.1860

25. Sakaguchi S, Hainberger D, Tizian C, Tanaka H, Okuda T, Taniuchi I, Ellmeier W (2015) MAZR and Runx factors synergistically repress ThPOK during $\mathrm{CD}^{+} \mathrm{T}$ cell lineage development. J Immunol 195(6):2879-2887. https://doi.org/10.4049/jimmunol.1500387 
26. Heng TS, Painter MW (2008) The Immunological Genome Project: networks of gene expression in immune cells. Nat Immunol 9(10):1091-1094. https://doi.org/10.1038/ni1008-1091

27. Lee YJ, Starrett GJ, Lee ST, Yang R, Henzler CM, Jameson SC, Hogquist KA (2016) Lineage-specific effector signatures of invariant NKT cells are shared amongst gammadelta T, innate lymphoid, and Th cells. J Immunol 197(4):1460-1470. https:// doi.org/10.4049/jimmunol.1600643

28. Engel I, Hammond K, Sullivan BA, He X, Taniuchi I, Kappes D, Kronenberg M (2010) Co-receptor choice by V alpha14i NKT cells is driven by Th-POK expression rather than avoidance of CD8-mediated negative selection. J Exp Med 207(5):1015-1029. https://doi.org/10.1084/jem.20090557

29. Engel I, Zhao M, Kappes D, Taniuchi I, Kronenberg M (2012) The transcription factor Th-POK negatively regulates Th17 differentiation in Valpha14i NKT cells. Blood 120(23):4524-4532. https://doi.org/10.1182/blood-2012-01-406280

30. Wang L, Carr T, Xiong Y, Wildt KF, Zhu J, Feigenbaum L, Bendelac A, Bosselut R (2010) The sequential activity of Gata3 and Thpok is required for the differentiation of CD1d-restricted $\mathrm{CD}^{+}$NKT cells. Eur J Immunol 40(9):2385-2390. https://doi. org/10.1002/eji.201040534

31. Enders A, Stankovic S, Teh C, Uldrich AP, Yabas M, Juelich T, Altin JA, Frankenreiter S, Bergmann H, Roots CM, Kyparissoudis K, Goodnow CC, Godfrey DI (2012) ZBTB7B (Th-POK) regulates the development of IL-17-producing CD1d-restricted mouse NKT cells. J Immunol 189(11):5240-5249. https://doi. org/10.4049/jimmunol.1201486

32. Egawa T, Eberl G, Taniuchi I, Benlagha K, Geissmann F, Hennighausen L, Bendelac A, Littman DR (2005) Genetic evidence supporting selection of the Valpha14i NKT cell lineage from double-positive thymocyte precursors. Immunity 22(6):705-716. https://doi.org/10.1016/j.immuni.2005.03.011

33. Liu X, Yin S, Cao W, Fan W, Yu L, Yin L, Wang L, Wang J (2014) Runt-related transcription factor 3 is involved in the altered phenotype and function in ThPok-deficient invariant natural killer $\mathrm{T}$ cells. Cell Mol Immunol 11(3):232-244. https://doi.org/10.1038/ cmi.2014.3

34. Tuttle KD, Krovi SH, Zhang J, Bedel R, Harmacek L, Peterson LK, Dragone LL, Lefferts A, Halluszczak C, Riemondy K, Hesselberth JR, Rao A, O'Connor BP, Marrack P, Scott-Browne J, Gapin L (2018) TCR signal strength controls thymic differentiation of iNKT cell subsets. Nat Commun 9(1):2650. https://doi. org/10.1038/s41467-018-05026-6

35. Abramova A, Sakaguchi S, Schebesta A, Hassan H, Boucheron N, Valent P, Roers A, Ellmeier W (2013) The transcription factor MAZR preferentially acts as a transcriptional repressor in mast cells and plays a minor role in the regulation of effector functions in response to FcepsilonRI stimulation. PLoS One 8(10):e77677. https://doi.org/10.1371/journal.pone.0077677

36. Naoe Y, Setoguchi R, Akiyama K, Muroi S, Kuroda M, Hatam F, Littman DR, Taniuchi I (2007) Repression of interleukin-4 in T helper type 1 cells by Runx/Cbf beta binding to the Il 4 silencer. $\mathrm{J}$ Exp Med 204(8):1749-1755. https://doi.org/10.1084/jem.20062 456

37. Setoguchi R, Tachibana M, Naoe Y, Muroi S, Akiyama K, Tezuka C, Okuda T, Taniuchi I (2008) Repression of the transcription factor Th-POK by Runx complexes in cytotoxic T cell development. Science 319(5864):822-825. https://doi.org/10.1126/scien ce. 1151844

38. Lee PP, Fitzpatrick DR, Beard C, Jessup HK, Lehar S, Makar KW, Perez-Melgosa M, Sweetser MT, Schlissel MS, Nguyen S, Cherry SR, Tsai JH, Tucker SM, Weaver WM, Kelso A, Jaenisch R, Wilson CB (2001) A critical role for Dnmt1 and DNA methylation in $\mathrm{T}$ cell development, function, and survival. Immunity 15(5):763-774
39. Lee YJ, Wang H, Starrett GJ, Phuong V, Jameson SC, Hogquist KA (2015) Tissue-specific distribution of iNKT cells impacts their cytokine response. Immunity 43(3):566-578. https://doi. org/10.1016/j.immuni.2015.06.025

40. Mao AP, Ishizuka IE, Kasal DN, Mandal M, Bendelac A (2017) A shared Runx1-bound Zbtb16 enhancer directs innate and innatelike lymphoid lineage development. Nat Commun 8(1):863. https ://doi.org/10.1038/s41467-017-00882-0

41. Osman Y, Kawamura T, Naito T, Takeda K, Van Kaer L, Okumura K, Abo T (2000) Activation of hepatic NKT cells and subsequent liver injury following administration of alpha-galactosylceramide. Eur J Immunol 30(7):1919-1928. https://doi.org/10.1002/15214141(200007)30:7\%3c1919:AID-IMMU1919\%3e3.0.CO;2-3

42. Biburger M, Tiegs G (2005) Alpha-galactosylceramide-induced liver injury in mice is mediated by TNF-alpha but independent of Kupffer cells. J Immunol 175(3):1540-1550

43. Wang H, Feng D, Park O, Yin S, Gao B (2013) Invariant NKT cell activation induces neutrophil accumulation and hepatitis: opposite regulation by IL-4 and IFN-gamma. Hepatology 58(4):14741485. https://doi.org/10.1002/hep.26471

44. Wondimu Z, Santodomingo-Garzon T, Le T, Swain MG (2010) Protective role of interleukin-17 in murine NKT cell-driven acute experimental hepatitis. Am J Pathol 177(5):2334-2346. https:// doi.org/10.2353/ajpath.2010.100028

45. Santodomingo-Garzon T, Swain MG (2011) Role of NKT cells in autoimmune liver disease. Autoimmun Rev 10(12):793-800 https://doi.org/10.1016/j.autrev.2011.06.003

46. Mattner J (2013) Natural killer T (NKT) cells in autoimmune hepatitis. Curr Opin Immunol 25(6):697-703. https://doi. org/10.1016/j.coi.2013.09.008

47. Lu Y, Zhong MC, Qian J, Calderon V, Cruz Tleugabulova M, Mallevaey T, Veillette A (2019) SLAM receptors foster iNKT cell development by reducing TCR signal strength after positive selection. Nat Immunol 20(4):447-457. https://doi.org/10.1038/ s41590-019-0334-0

48. He X, He X, Dave VP, Zhang Y, Hua X, Nicolas E, Xu W, Roe BA, Kappes DJ (2005) The zinc finger transcription factor ThPOK regulates CD4 versus CD8 T-cell lineage commitment. Nature 433(7028):826-833. https://doi.org/10.1038/nature03338

49. Sun G, Liu X, Mercado P, Jenkinson SR, Kypriotou M, Feigenbaum L, Galera P, Bosselut R (2005) The zinc finger protein cKrox directs CD4 lineage differentiation during intrathymic $\mathrm{T}$ cell positive selection. Nat Immunol 6(4):373-381. https://doi. org/10.1038/ni1183

50. Wang L, Wildt KF, Castro E, Xiong Y, Feigenbaum L, Tessarollo L, Bosselut R (2008) The zinc finger transcription factor Zbtb7b represses CD8-lineage gene expression in peripheral $\mathrm{CD}^{+} \mathrm{T}$ cells. Immunity 29(6):876-887. https://doi.org/10.1016/j.immun i.2008.09.019

51. Vacchio MS, Wang L, Bouladoux N, Carpenter AC, Xiong Y, Williams LC, Wohlfert E, Song KD, Belkaid Y, Love PE, Bosselut R (2014) A ThPOK-LRF transcriptional node maintains the integrity and effector potential of post-thymic $\mathrm{CD} 4^{+} \mathrm{T}$ cells. Nat Immunol 15(10):947-956. https://doi.org/10.1038/ni.2960

52. Wang H, Hogquist KA (2018) CCR1 defines a precursor for murine iNKT cells in thymus and periphery. eLife 7:e34793. https ://doi.org/10.7554/elife.34793

Publisher's Note Springer Nature remains neutral with regard to jurisdictional claims in published maps and institutional affiliations. 